San Jose State University

SJSU ScholarWorks

Master's Theses

Master's Theses and Graduate Research

2005

\title{
Exploring the themes in India currents magazine using narrative analysis
}

Priya Gopalakrishnan

San Jose State University

Follow this and additional works at: https://scholarworks.sjsu.edu/etd_theses

\section{Recommended Citation}

Gopalakrishnan, Priya, "Exploring the themes in India currents magazine using narrative analysis" (2005). Master's Theses. 2833.

DOI: https://doi.org/10.31979/etd.n3kx-9ww3

https://scholarworks.sjsu.edu/etd_theses/2833

This Thesis is brought to you for free and open access by the Master's Theses and Graduate Research at SJSU ScholarWorks. It has been accepted for inclusion in Master's Theses by an authorized administrator of SJSU ScholarWorks. For more information, please contact scholarworks@sjsu.edu. 
EXPLORING THE THEMES IN INDIA CURRENTS MAGAZINE

\title{
USING NARRATIVE ANALYSIS
}

\author{
A Thesis \\ Presented to \\ San Jose State University \\ In Partial Fulfillment \\ of the Requirements for the Degree \\ Master of Science
}

The Faculty of the School of Journalism and Mass Communications

by

Priya Gopalakrishnan

December 2005 
UMI Number: 1432451

\section{INFORMATION TO USERS}

The quality of this reproduction is dependent upon the quality of the copy submitted. Broken or indistinct print, colored or poor quality illustrations and photographs, print bleed-through, substandard margins, and improper alignment can adversely affect reproduction.

In the unlikely event that the author did not send a complete manuscript and there are missing pages, these will be noted. Also, if unauthorized copyright material had to be removed, a note will indicate the deletion.

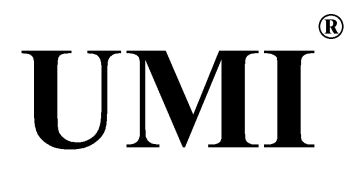

UMI Microform 1432451

Copyright 2006 by ProQuest Information and Learning Company.

All rights reserved. This microform edition is protected against unauthorized copying under Title 17, United States Code.

ProQuest Information and Learning Company 300 North Zeeb Road

P.O. Box 1346

Ann Arbor, MI 48106-1346 
(C) 2005

Priya Gopalakrishnan

ALL RIGHTS RESERVED 
APPROVED FOR THE SCHOOL OF JOURNALISM AND MASS COMMUNICATIONS
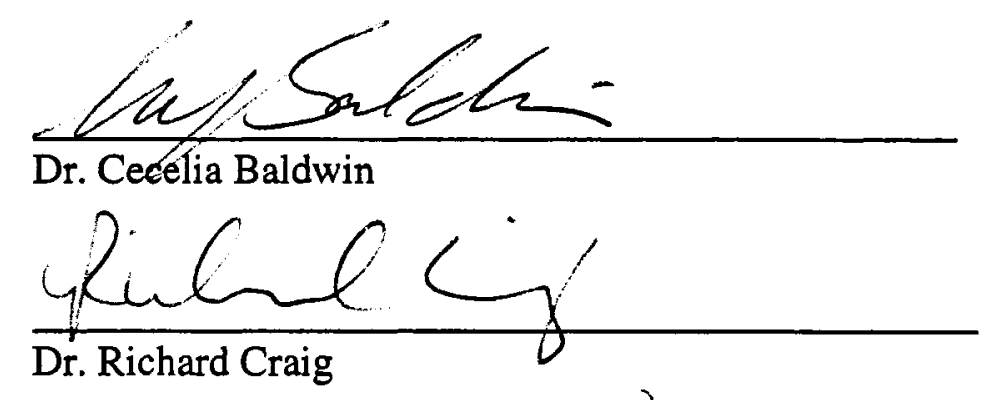

Dr. William Tillinghast

APPROVED FOR THE UNIVERSITY

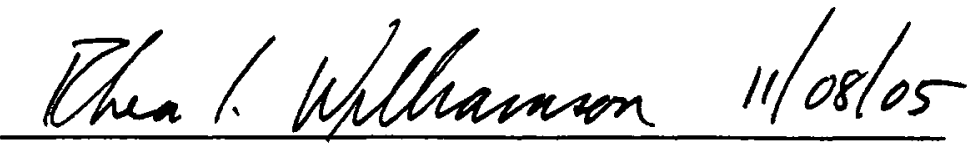




\section{ABSTRACT \\ EXPLORING THE THEMES IN INDIA CURRENTS MAGAZINE USING NARRATIVE ANALYSIS \\ by Priya Gopalakrishnan}

This thesis examines the themes in India Currents magazine using narrative analysis. This magazine is primarily targeted towards the Indian immigrant community in the Bay Area, California. The approach is to analyze the function of immigrant media in the acculturation process of immigrants.

Narrative analysis and examination of the frames are used to study the acculturative experiences of India immigrants in the Bay Area, as seen from the point of view of the magazine. The characters, themes, and images portrayed, and the meta-story that flows through the entire narrative, are analyzed. Selected terms that would indicate the level of acculturation in the narrative are also studied.

The findings show that narrative changed with the change in population. The frames, the words, and the meta-narrative evolved, reflecting the changing position of the Indian immigrant. 


\section{ACKNOWLEDGEMENTS}

I wish to thank my advisors, Dr. Cecelia Baldwin, Dr. Richard Craig, and Dr. William

Tillinghast, for their encouragement and support. In addition, thanks are due to $\mathrm{Mr}$.

Ashok Jethanandani, editor of India Currents magazine and his staff for all their cooperation. Finally, I wish to thank my family for their patience. 


\section{TABLE OF CONTENTS}

Chapter

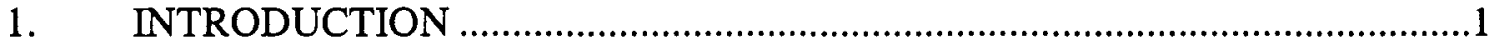

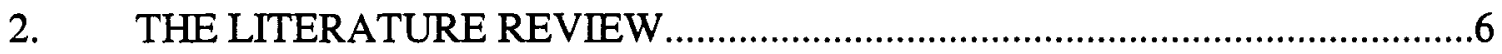

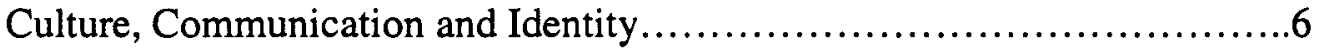

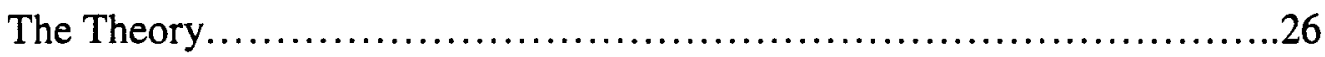

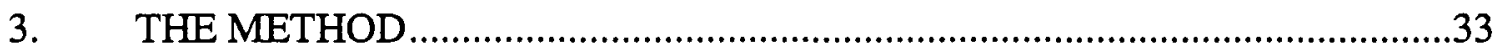

Preliminary Research...........................................33

Basic Concepts..................................................

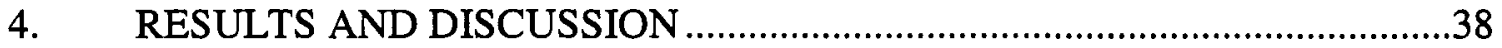

Structure and Role of the Magazine .....................................................38

Frames Used........................................................

Narrative Analysis...............................................41

Results of the Analysis of Selected Terms.............................61

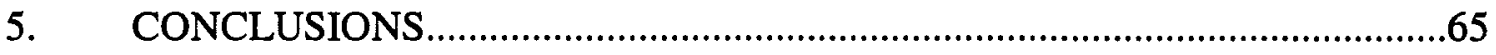

Limitations of this Study......................................67

Directions for Future Research....................................68

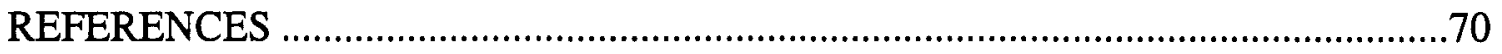




\section{List of Tables}

Table Number

1. Results for the term Home.........................................62

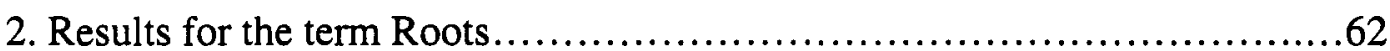

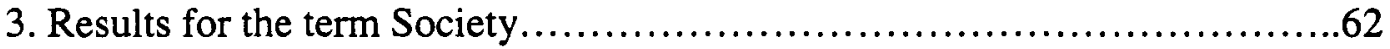

4. Results for the term Culture..............................................63

5. Results for the term Tradition..........................................63

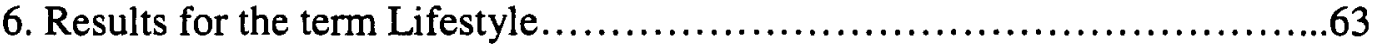

7. Results for the term Immigrant......................................64

8. Results for the term Involvement....................................64

9. Results for the term Identity......................................64 


\section{CHAPTER 1}

\section{INTRODUCTION}

History is the record of human endurance and survival in the face of wars, natural calamities, and economic difficulties. Change for the better or worse being inevitable, the only way for people of all countries to move forward, is to embrace this change and seek opportunities in it. Migration to other countries in search of a better life is one of the ways through which people choose to make a change in their lives, immediate environment, and social context. Though this is often a voluntary choice, the change is not easy as immigrants grapple with strange, even hostile host countries, cultures, and work environments.

Historically, the people of the Indian subcontinent have faced change in multiple ways through centuries. Apart from being susceptible to environmental devastations of droughts, floods, and earthquakes, India has also been subjected to cultural changes through visitations and conquests from peoples across its borders. The Aryans, who established themselves in India between 1500 and 800 B.C., at the time of the Indus Valley Civilization, were themselves the earliest settlers, according to the Manas Web site on Indian history. From as early as 1000 A.D., India has been overrun by invaders such as the Afghans, Turks, Moguls, and later, by colonialists such as the British, the French, and the Portuguese. There have also been cultural influences absorbed from visitors from China, Nepal, and Tibet. All these have had a profound impact on the Indian culture. Apart from the historical influences, India, even today, is a melting pot of diversity. Apart from Hinduism and Islam, many other religions are also practiced by the 
people of the country. Each state in India has its own distinct regional language, culture, traditions, customs, and identity. Even within a particular community, there are nuances of identity, behavior, and traditional observances. It is this baggage of culture that an immigrant from India carries when transplanted into a different country. For the purpose of this study, the term "Indian," will be used to refer to the culture, language, traditions and persons whose country of origin is India. The words "he" and "his" will be used to refer to the Indian immigrant, irrespective of gender.

Emigration is not a new phenomenon to India. According to the 2001 Indian Census, Indian immigrants around the world totaled 11 million persons, as cited by Jeanne Fredrickson in India Currents magazine. And in the US alone, the immigrant Indian population was 1.6 million, or 0.6 percent of the total US population, according to the 2000 US Census. The immigrant Indian population in the US has recorded a phenomenal growth of $105.87 \%$, becoming the fastest growing community in the US, and also the third largest Asian group after the Chinese and the Filipinos, according to the US Census Bureau (2000).

The exceptional growth rate of Indian immigration has been largely due to the relaxation of the immigration laws after 1990 and due to the technological boom of the late 1990s. However, due to technological advances, interconnectivity between nations has increased and palpably altered the position of these immigrants; although they are a displaced minority, they are relatively more connected to their homeland than their earlier counterparts. The Indian immigrant to the US today is exceptionally rich in the number and kinds of media choices that are at his disposal. He can access local American media, 
media from India, which is also readily available, and immigrant media. Cultural experience now becomes a matter of choice, rather than of necessity.

Acculturation is the phenomenon resulting from the intermingling of host and heritage cultures, which occurs at the time of an immigrant's adaptation to his new environment. This varies according to factors specific to each community of immigrants. It depends on factors such as the community's cultural characteristics; the period they immigrate in and the host country they immigrate to; the intention of the community with regard to acculturation and openness to acculturation; and the level the community is allowed to acculturate due to the differences in the heritage culture and physical characteristics. Earlier theories, such as the melting-pot theory, have stressed that differing cultures, over time, would lose their unique characteristics and join the mainstream. This was found to be especially true of earlier immigrants, such as the Poles, Italians, Irish, Greeks, and Slavs, who willingly gave up their heritage to become "Americanized" (Novak, 1971). This theory however, does not hold good for the latest group of Indian immigrants to the USA; this group has the resources and the inclination to hold on to its heritage culture.

Immigrant or ethnic media play an important role in the process of acculturation. For the purpose of this study, the terms immigrant media and ethnic media will refer to the media produced by and primarily for the immigrant ethnic community. The terms can also be used interchangeably.

According to Park (1971), ethnic media were primarily initiated to help immigrants cope with the adjustment to a new land, habits, and customs and thereby 
hasten acculturation. Immigrant media started out on a small scale; it has come a long way from the early beginnings. From being a compilation of services and opportunities available in the neighborhood, it now performs valuable community functions; it serves as a platform for the heritage culture and the political ideologies of the community. Though there are still a number of small publications for which the main revenue is advertising from local businesses, many have grown to have a daily circulation with a wide audience. Indian ethnic media has yet to reach this level of stability, but they are growing fast and the growth rate of the minority population as well as the reach of these publications gives them a very high potential indeed.

If the minority media and the minority audience have changed today, the role of the media has also changed. In fact, Jeffres (2001) stressed that "ethnic media use leads to stronger ethnic identification across time" (p. 496) and noted that "there is evidence of accumulative effects . . . stronger ethnic identification leads to greater ethnic media use over time" (p. 516). He highlighted the concept of biculturalism in which individuals successfully straddle two cultures, without losing their identity or maintaining any one culture exclusively. According to Jeffres, in today's multicultural society, diversity in culture is appreciated and even sought after. Relinquishing the heritage culture becomes unnecessary as the immigrant's roots become a valuable part of his identity. Contributions to international culture now come from all around the world and ethnic media can capitalize on this opportunity to provide unique content. Jeffres forecasted that, in the future, the struggle of loyalties to different cultures may not even exist, and 
that the interplay between different cultures could provide media content with the broadest appeal.

In this thesis, the researcher conducted a Narrative analysis and researched the frames used, of the content of a Bay Area Indian magazine, India Currents. The purpose of the study was to explore the narratives in this magazine and how it represents the immigrant experience. According to Kim (1988), who noted that print media play an essential role in the communication network of any ethnic community, "Ethnic communication processes reinforce the original cultural patterns in strangers as they continue to practice the use of verbal and non-verbal symbols of the original culture and all its implicit communication rules" (p. 122). This study focused on highlighting the patterns and symbols woven into the text of the magazine.

There has been little research done so far on the acculturation of the Indian immigrant community, and especially on the role of the Indian immigrant media; narrative analysis too, has been little used in this kind of cultural study. The cultural pressures today are different, with the rapidly growing tolerance, if not acceptance, of different cultures, and there are the specific characteristics of the Indian immigrant population that make it unique. These factors significantly influence the relevance and content of the Indian immigrant media. As an Indian immigrant, an observer and onetime contributor to this niche medium, this researcher feels that it will grow to have a significant presence and that this study will contribute to the knowledge of this specialized medium. 


\section{CHAPTER 2}

THE LITERATURE REVIEW

\section{Culture, Communication, and Identity}

Language, communication, and culture are inextricably linked and participation in any one will involve the other two. This was stressed by the cultural school, and Carey (1989) noted that, "To study communication is to examine the actual social process wherein significant symbolic forms are created, apprehended and used" (p. 30). The symbols which have a special meaning beyond the one that is manifest become the foundation of our customs, traditions, and culture. Although language is the most basic unit of all communication, it too cannot be completely devoid of the influence of the communicator's culture. This was also the stance of the quantitative school; McLeod and Chaffee (1973) stressed this when they defined language as, "a system of significant symbols ... a system of shared behavior, based on assumed cognitive correspondences" (p. 473).

The relation between communication and culture is symbiotic. McQuail (2000) asserted that, "The most general and essential attribute of culture is communication, since cultures could not develop, survive, extend and generally succeed without communication" (p. 93). He added that the cultural school emphasizes "media use as a reflection of a particular socio-cultural context and as a process of giving meaning to cultural products and experiences in everyday life" (p. 367). Communication, therefore, becomes a method to give meaning to events and experiences as they are communicated to an audience; this communication could be as simple as a conversation about the day or 
a traditional event, such as a wedding, which communicates about the persons, their faith and tradition to the community. Carey (1973) also stressed that, "communication is viewed as a process through which a shared culture is created, modified and transformed" (p. 177).

In addition, Jeffres (2000) noted that, "Communication patterns are important in passing on culture from one generation to the next and in maintaining one's culture across time" (p. 497). These patterns and their maintenance are significant, especially in the context of cultural change. According to Jeffres (2000), cultural change can take place at two levels: at the societal level, it can lead to change in population shifts or cultural norms and, at the individual level, it can lead to acculturation.

\section{Acculturation}

Acculturation studies were first conducted by anthropologists in the 1930s. One of the earliest studies of acculturation was by a group of three anthropologists: Robert Redfield, Ralph Linton, and Melville Herskovits (1936) who noted that, "Acculturation comprehends those phenomena which result when groups of individuals having different cultures come into continuous first-hand contact, with subsequent changes in the cultural patterns of either or both groups" (p. 149). They also distinguished acculturation from culture-change, which is but one aspect of it; from assimilation, which could be a phase in the acculturation process, and from diffusion which could take place without direct contact.

According to Kim (1988), the earliest research in the field of acculturation was by anthropologists and sociologists, and had focused on the impact on groups of immigrants, 
rather than the individual. And while anthropologists are interested in the culture change that this involves, sociologists focus on the political and socio-economic ramifications of this process. Kim also stressed that while previous research considered the final goal of acculturation to be assimilation, this is not so today. According to Kim, "This vision of assimilation as the final goal of cross-cultural-adaptation was first questioned when blacks challenged its validity through their Civil Rights Movement of the 1960's, preparing the way for a similar awakening among other ethnic groups," (p. 17) and scholars today focus more on the ethnicity of different immigrant groups.

Klinger and Bierbrauer (2001) defined acculturation as, "An interactive process that results from the influences of both the heritage culture of the immigrant and the culture of the host society" (p. 190). According to them, immigrants who are newcomers to an established culture face changes in their environment, such as social customs, language, religion, and food. The minorities deal with this conflict by interpreting it and adapting to it. While the immigrant culture will also influence the host culture, it is the minority culture that will be affected the most; "thus, acculturation can be conceptualized as the intervening process that links both the influence of the immigrant's heritage culture and the culture of the dominant society" (Klinger \& Bierbrauer, p. 190).

Berry (1990) distinguished between the two levels of acculturation; at the population level and at the individual level. He analyzed the key elements involved in the process: continuous and first-hand interaction between cultures, change in the cultural or psychological phenomena among the people in contact, and the difference between the process which may be dynamic and the state it results in. 
Berry (1990) also identified the two issues that influence this process-the degree to which minority members wish to retain their culture and heritage, and their desire to establish a positive relationship with the host society, which is probably necessary for continued interaction. He categorized four of levels of cultural maintenance and adaptation: a) Assimilation, which expresses the wish to join the dominant culture and relinquish initial identity completely; b) Integration, which implies the desire or interest to maintain close contact with both the heritage culture and the dominant culture and to participate in the social framework; c) Separation, which describes avoidance of the dominant culture and total adherence to the heritage culture; and d) Marginalization, which means maintenance of loose contact with both the dominant and the heritage culture, being accepted or supported by neither one.

Klinger and Bierbrauer (2001) distinguished between structural influences and interpersonal influences on the process of acculturation and emphasized the fact that all aspects of a person's life are not likely to be influenced to the same level or in the same direction. Berry (1990) agreed with these aspects and identified variables that influence the process, such as purpose and length of contact, status of the immigrant, and his cultural, political, and economic qualities.

Although Berry (1990) also discussed involuntary or forced acculturation, for example, among refugees or colonized peoples, he concurred with Azjen (1989) that for voluntary acculturation, the intention to acculturate is the strongest predictor to actual behavior. Azjen's "theory of planned behavior" stressed that, "Intentions are assumed to capture the motivational factors that impact on a behavior" (p. 250). Azjen identified 
three determinants of intention: the attitude towards behavior, which is individual and could be positive or negative; the subjective norm, which refers to the perceived social pressure, an important factor for those whose cultures are community oriented; and the degree of perceived behavioral control, which refers to the ease of performing the behavior based on past experiences. These factors are especially important when we look at the acculturation of an individual from a culture which is very different to the host culture, such as the acculturation of immigrants from Asia in the United States.

\section{Ethnic Identity}

According to Phinney (2003):

Ethnic identity is a dynamic multidimensional construct that refers to one's identity or sense of self as a member of an ethnic group. Ethnic groups ... claim a common ancestry and share one or more of the following elements: culture, phenotype, religion, language, kinship, or place of origin. (p. 63)

Phinney (2003) notes that apart from European ethnic groups, complete acceptance of other groups by the host society in the US has not yet been reached. This motivates a strong ethnic identity, which can provide a sense of solidarity in the face of discrimination.

According to Tajfel, (as cited in Kim, 1988), "social identity" can be defined as "that part of an individual's self-concept which derives from his [her] membership in a social group [or groups] together with the value and emotional significance attached to that membership" (p. 21). Kim noted that in the case of immigrants, there is a significant difference between those that have access to ethnic communication networks and those that don't; this accessibility will differentiate in the maintenance of their ethnicity. Jeffres (2000) stressed that ethnic identification is "one's perceived self-designation and 
affective attachment to one's ethnic heritage" (p. 501). An individual may identify himself with more than one group and ethnic behavior involves maintaining the ethnic language and customs. And according to Wagle (1995), "each person and each subgroup in a multicultural setting is constantly seeking to understand the "other" and redefine the "own self" in that light" (p. 2).

It is in this transmission of cultural information and in satisfying those seeking to confirm their cultural identity that ethnic media play a vital role. In fact, for immigrants, reading of a newspaper can be more that just accessing information, it could become "a situation in which nothing new is learned, but in which a particular view of the world is portrayed and confirmed" (Carey, 1989, p. 20).

Immigrants to the USA

Although America has been called a land of immigrants and the ethnic landscape has been constantly in a state of flux, the process of immigration has not always been easy. Successive waves of immigrants coming in after the change in immigration laws in 1965,1985 , and 1990 have contributed to make the country what it is today.

Wilson and Gutierrez (1995) noted that the majority of the earlier immigrants to America in the late 1800 s and 1900 s were from European nations and they assimilated to form the new majority of the country. The melting pot theory held true at this time; "immigrants who came to the United States, would, within a relatively short period of time, cast aside their European identities, cultures and languages as they forged or were forced to adopt the loyalties, customs and language of their new home" (Wilson \& Gutierrez, p. 6). This theory stressed that such assimilation was necessary to fully 
participate in the new society, and for this reason, most of the first and second generation immigrants of this period relinquished hold on their native culture.

However, some such groups, which did not blend in or were not allowed to assimilate because of their race or physical appearance, did not experience the melting pot. Their experience, according to Wilson and Gutierrez (1995) has been more in the form of a stew, where each community has its own distinct identity, yet forms part of a whole.

This has been particularly true of Indian immigrants, who have a distinctly different culture. Lassiter (1998) found that most Asian Americans are group-oriented, placing a high value on filial piety, educational achievement, family loyalty, and respect for authority. This is in contrast to the traditional American emphasis on individualism, enterprise, and self-reliance. Family systems, religious beliefs, practices, and even eating habits—many Indians do not eat meat, or at least some kinds of meat—all serve to distinguish Indian immigrants from the local populace. In addition, most of the later wave of Indian immigrants are also highly educated and employed in a well-paid and professional capacity. This may limit the need for their inter-mingling with the host culture and reflect a disposition as well as the ability to keep the links with their heritage alive.

\section{History of Indian Immigration}

The first Indian immigrants to the United States were the Sikhs from the Punjab, who came to work as laborers in the early $19^{\text {th }}$ century and many of whom settled down to farming in the State of California. There was a lull in new arrivals after the early Sikh 
immigration, which is reported as early as 1899 , according to the Pioneer Asian Indian Immigration to the Pacific Coast Web site. It was not till the late $19^{\text {th }}$ century that a more diverse group of swamis, students, and merchants arrived. In fact, when compared with immigration rates of other groups, most of the Indian immigrants to the United States have arrived relatively late, many of them after 1965. Apart from farming in California, some of the economic sectors where Indians have focused on are: the hotel-motel industry, the operation of 7-11 stores, diamond trading, especially in the New York Diamond District, transportation (a majority of cab-drivers are Punjabi Sikh), and gasstation owning and operating (Mazumdar, 1993). Until 1993, their population was mainly concentrated in the Northeastern states of the US. It is only recently, due to development of the technology industry in Silicon Valley in California that this population in the San Francisco Bay Area has increased.

A great number of the later wave of Indian immigrants arrived during the $\mathrm{Y} 2 \mathrm{~K}$ crisis. They were highly qualified, holding professional positions, and many were employed by the technology industry. Fischetti (2000) noted that, "In 1996, of the estimated 2000 hi-tech companies in California's valley, nearly 500 were run by AsianAmericans" (p. 104). These immigrants are very much a part of the "model minority". In fact, Daniels (2000) asserted that "Indians represent a talent and capital drain from India, a talent and capital infusion for the United States" (p. 364). According to Portes and Rumbaut, (as cited in Vishwanath \& Arora, 2000)

The Indian ethnic community in the United States is about 1 million strong ... geographically widely dispersed with largest concentrations in major urban centers. Most of them speak English and enjoy high formal education, most are in 
professional occupation, and they have one of the highest average household incomes of any ethnic group in the United States. (p. 44)

There is a great difference in the thinking and mentality of these successive waves of immigrants with regard to their heritage and the dominant culture. The earlier Punjabi immigrants, who left India in the 1900 s, were unemployed artisans and farmers whose emigration was motivated by economics. "The Sikh emigration throughout this period and continuing up to the 1950 s and 1960 s included not only members of the poor, marginalized peasantry who were forced to seek employment elsewhere, but also middleand upper-middle-class farmers" (Fernandez, 2000, p. 69). They tried to evoke the atmosphere of home in the new land, perhaps in denial of their migration.

For example, to cite Leonard's (1997) opinion of the Punjabi immigrants, "they visualized their new locality in terms of the old, using familiar landmarks to ground their new identity" (p. 126), finding similarity between the Punjab and California landscapes. Fischetti (2000) discussed this thinking when he stressed that today, "Most AsianAmericans are voluntary immigrants, drawn to the US in part by the dream of success. Such immigrants see cultural differences as something to be overcome, while involuntary groups tend to cherish differences" (p. 103).

Apart from the difference in the acculturation of immigrants entering the country at different points of time due to different causes, there are also other differences in the Indian immigrant population. Portes and Rumbaut (1990) noted that though relatively homogenous in terms of education, occupation, and income, the Indian immigrant community is diverse in terms of linguistics and religion, (as cited in Vishwanath \& Arora, 2000). According to Mallapragada (2000), "India is an extremely diverse society 
and naturally, this diversity is reproduced in the diaspora," (p. 180). India's own cultural tolerance which allows religious groups as diverse as Hindus, Muslims, Jews, Sikhs, and Parsis room to breathe and co-exist has also contributed to each community maintaining and holding on to its cultural identity. So, although there are commonalities along religious, regional, occupational or other aspects, there is a constant struggle to connect as most Indians inhabit many identities; identities of religion, area of origin, and language.

The Diaspora

According to Mallapragada (2000), "the term diaspora, initially used to refer to the migration of the Jewish people, evokes the notion of loss of homeland, dispersal and the rebuilding of lives in alien cultures" (p. 180). The common feature of many displaced or diasporic communities is the nostalgia for home. Mallapragada noted that the Indian immigrant is affected by no less a longing for home and in an attempt to recreate and share with other immigrants, creates the interesting concept of the "imagined" community. This is to forge a sense of cultural and social belonging and to create a common identity; Mallapragada also noted that,

While the past operates to create a sense of community, the present also allows for the regrouping of people around some commonality, for example, the website www.bayareaindian.com, whose primary audience is the Indians who live in the San Francisco Bay Area. (p. 182)

\section{Immigrant Media}

According to Park (1971), the ethnic media are a product of immigration and without immigration there probably would not be any ethnic media, "Loneliness and an unfamiliar environment turn the wanderer's thoughts and affections back upon his native 
land. The strangeness of the new surroundings emphasizes his kinship with those he has left" (p. 49). Park stressed that the ethnic media were primarily started to smoothen the assimilation process of the early immigrant.

A concept of interest here is acculturative stress, which occurs when people from a distinctly different culture are acculturated to another as the process is stressful. Berry (1975) noted that it is caused by the nature of behavior learnt in a particular culture and the psychological distress caused during transformation. Berry added that "the greater the incongruity between the two cultural and behavioral systems, the greater the conflict and resistance associated with the transition, and the greater the resultant acculturative stress" (p. 226). Ethnic media could contribute to a reduction in acculturative stress by providing the immigrant information and resources for easier acculturation, highlighting the heritage culture he hails from, providing stories of successful immigrants and by keeping him in touch with his culture of identity.

As Park (1971) discussed, the immigrant press helps to "facilitate the adjustment of the foreign born to the American environment" (p. 87). It may print local news to fulfill the immigrant's need to learn about American ways, customs, and events, if only to help the immigrant survive, and thus accelerate the process of acculturation. According to Park, whether the news media will help the immigrant participate in society will indicate its effectiveness.

The reason for using ethnic media by differing groups of immigrants will vary. According to Park (1971), most ethnic media maintain a low-brow tone to communicate with the common man; this standard obviously cannot be applied to the Indian immigrant 
media, whose readers are often well-read and interested in art and culture. Also, the new Indian immigrants are linguistically better equipped to survive in English speaking countries, because of their familiarity with the language.

As a comparison, if we look at Chinese immigrants, Tillinghast (1998) noted that "fluency in English is the key determinant of Chinese-language media use and that there is an especially high reliance on Chinese media by those who are not comfortable using English" (p. 46). The Chinese immigrant may, in fact, decide to use English media to attain fluency in that language, a need which would not be felt by Indian immigrants. The Indian immigrant's fluency in English is illustrated by the fact that there are a number of Indian ethnic publications in English. Zhou and Kai (2002) also found that though Chinese immigrant media were born to support burgeoning businesses, they soon became an independent economic business. Indian immigrant publications too, are fast reaching this level of stability and popularity.

Gillespie (2000) stated that the new means of communication have considerably reduced the boundaries set by distance and by bringing the heritage culture into the diaspora have increased the choices for identification of the migrant communities. There is an increased connection with the diaspora and diminishing of the importance of and the identification with the national or majority culture. Vishwanath and Arora (2000) agreed that the new wave of immigrants is advantageous in this direction:

Aided with the modern means of communication, the new immigrants are able to maintain their links to the homeland relatively more easily than the earlier wave of immigrants .... immigrant media function as one of the principal vehicles of socialization and communication within immigrant communities. (p. 41) 
Park (1971) found that immigrant media flourished in primarily urban areas, because of the high concentration of immigrants in those areas. He also wrote that it is easier to start a publication in an ethnic language than in English as it requires lesser capital and faces less competition. Park (1971), and Mody and Valdez (1983) agreed that advertising by local ethnic businesses is the primary source of revenue for these media and that the kind of advertising featured may also locate where the media are on the acculturation scale.

One potential problem for the Indian immigrant press that Vishwanath and Arora (2000) identified is the area of conflict reporting as the ethnic press may want to maintain the image of hard-working immigrants and so would not want to emphasize any internal problems within the community. Another issue is, "It must report on a pluralistic system such as India to a homogeneous Asian Indian Ethnic Community in the United States" (Vishwanath \& Arora, p. 46).

According to Vishwanath and Arora (2000), these are the functions of the ethnic media:

1. Informational Function: The ethnic media fulfill the dual purpose of keeping the immigrants in touch with not only within the local community, but also with their native homeland. As the mainstream media in the United States have little interest in covering international news, immigrants rely on the ethnic press for news from home. 2. Assimilatory Function: As immigrants try to adapt to the host country, positive coverage by the ethnic media on their participation in local activities, promotes a 
good vibe between the immigrants and their host country and encourages assimilation.

3. Cultural Transmission: Coverage on the ethnic religious and cultural functions strengthens the cultural heritage among the community and among their children, the next generation as well.

4. Community Booster: Focus on success stories of immigrants as well as human interest stories projects a positive image of the community to its members and to the external public.

5. Community Sentinel Function: the press plays an assertive role in coverage of the rights of the immigrants and the issues which might affect them.

In these last two functions the ethnic newspaper behaves like a community paper. According to Park (1971), “The immigrant press serves . . . to maintain contact and understanding between the home countries and their scattered members in every part of the United States" (p. 55). The editors try to use the press as a bridge between the old and the new cultures. Hsu (2002) analyzed that ethnic media have a political voice as well and eventually shape the identity of the community. "In similar times of crisis, the ethnic press has habitually hosted the pesky, difficult, and ultimately unpopular questions that would likely invite censure were they voiced in the mainstream" (p. 7).

Mody and Valdez (1983) concured with Vishwanath and Arora (2000) that the ethnic media "function as an information loop that circulates information within respective communities" (p. 3). Their primary information source is their community and their focus is on dissemination of information as well as culture. 
Mody and Valdez (1983) also noted that: a) The ethnic media define their audience in racial terms rather than geographically, and they probably fulfill a need not being met; b) The community of interest is largely homogeneous and so they become a 'special-interest' and not mass, media; c) There is a strong relationship between the cost of production and use, and for this reason, print media are well patronized, by publishers and users. Advertising is the main source of revenue for the commercial print media.

Cost and distance are the two constricting features which make connecting to other Indian immigrants in the United States a difficulty, two features which do not limit the Internet at all. Therefore, "given the overwhelming contribution of Indian immigrants to the hi-tech industry based primarily in Silicon Valley, it is no surprise that the Internet is the medium used for forging business ties and networking with professionals" (Mallapragada, 2000, p. 180). In fact, Jefferes (2001) stressed that "ethnic media appear to act as vehicles that help ethnics retain attachment to their culture over time" (p. 521).

The ethnic media, while assisting in propagating the heritage culture also encourage the immigrant to find his place in the new society. Bhowmick (1997) pointed out that the Indian immigrants' special attachment to their motherland and their reluctance to acculturate into the United States along with their relative affluence causes hatred and jealousy among those who resent their foreignness. He urged "acculturation, mainstreaming and social integration by adopting appropriate missions and ... engaging in a suitable range of activities from positive political influence to social and cultural involvement” (\$ 2). 
Previous Research on Acculturation and Ethnic Media

Ethnic media were started initially to accelerate the process of acculturation, and over time, with successive waves of immigrants, the relationship between ethnic media use and acculturation has not been a constant one. Earlier research in the field of ethnic media and acculturation indicates that many other factors play a role in the acculturation process of immigrants, such as the integration in family and kinship, as studied by Nauck (1989), and the personal communication network developed by immigrants themselves, as noted by Lam (1980). Also, according to Kim (1978), with regard to acculturating in the host society, "the immigrant's use of ethnic media rapidly decreases over the years, while that of American media steadily increases" (p. 197). Therefore, unless there are further incoming waves of immigrants, the immigrant media eventually work themselves out of an audience.

This finding is also supported by the study by Blau, Thomas, Newhouse, and Kaavee (1998) who stressed that the "(immigrant) newspapers are founded as new immigrants arrive and therefore, they primarily play a role in the reception of newcomers and not in the establishment and maintenance of ethnic communities" (p. 34). This study found that the ethnic newspapers were short-lived (lasted less than two years), were in sync with the numbers of new arrivals, reduced fears of the hostile new environment and were therefore of less importance to the resident ethnic population. Blau et al. also noted that an ethnic identity was constructed, and that this expression of a distinctive identity was significant when the ethnic diversity was high in the demographic region. 
This idea of ethnic identity is especially important, when we see that according to Lam (1980), "Exposure to ethnic media appear to play a 'subsidiary role' in the process of acculturation in comparison with openness to the Canadian mass media" (p. 77). Lam points out that the ethnic media may serve as a bridge between the new society and the old and can act as "a means through which immigrants can ease their emotional attachment" (p. 88). Also, the study of usage of ethnic media by Korean immigrants in Chicago by $\operatorname{Kim}$ (1978) shows that the exposure to ethnic media did not familiarize the immigrants with the signs and symbols of Canadian society. This serves to reinforce the fact that use of ethnic media by immigrants can be for reasons other than acculturation, such as for reassurance about their choice to migrate or to keep them informed about their heritage culture, and other such reasons.

Increasing Growth Rate of Ethnic Media

Although Jeffres (2001) noted the importance of parent-child communication in passing on culture and tradition, other communication channels play a significant role as the next generation matures. "As a result of cultural contact, social influences that are involved in the acculturation process transform an individual so that his or her cultural features are no longer identical to those existing prior to the first contact" (Klinger \& Bierbrauer, 2001, p. 198).

As the ethnic media fulfill a need not being met by the mainstream media, and the minorities are growing in size as well as in purchasing power, many organizations such as Hearst and Knight-Ridder look to the idea of acquiring it to reach this prosperous market segment. According to Cornitcher (1999), "Research and demographic figures 
confirm that African American, Hispanic and Asian segments are growing in population and purchasing power-so fast, in fact that the combined groups will soon become the majority population in the 21 st century" (p. 18). And Hua (2002) noted that more than $84 \%$ of the minority group reported that they had some contact with ethnic media and that they paid more attention to advertisements in ethnic media rather than mainstream commercial ones. The growth in Indian ethnic media is part of this larger trend, as marketers and advertisers realize the potential of this neglected market.

This phenomenon of companies showing interest in ethnic media can be seen in the example of BET, which was acquired by Viacom. In fact, marketers realize, as reported by Lee and Tse (1994), that new immigrants are often informed about what products to buy and where to buy them through the ethnic media and acculturation studies are also being done by them to consider which media to target. Increasing Growth Rate of the Indian Immigrant Population in the Bay Area According to the Bay Area Census, the Indian population in the Bay Area has increased steadily. The India Community Center Web site notes that the Indian segment of the immigrant population is the fastest growing of the Asian segment, increasing $106 \%$ from the years 1990-2000. Approximately 26,000 Indian immigrants enter the US every year on student visas and another 74,000 Indians enter the US on temporary work visas. The four main Bay Area counties where the Indian population is concentrated are San Jose, Fremont, Sunnyvale, and Santa Clara, where the increase in population in the decade $1990-2000$ for these localities has been $149 \%, 272 \%, 528 \%$, and $318 \%$, according to the Web site. 
As has already been mentioned in this paper, this immigrant group, which is welleducated and affluent, has considerable purchasing power. With the election of Bobby Jindal to the Congress in 2004-the first American of Indian origin to achieve this since 1956, when Dalip Singh Saund became the first Asian American to be elected to the US Congress-it also seems as if the Indian immigrants are ready to take their significant role in society. Ethnic media now become a powerful tool to communicate with a minority population which is attractive to both audience seekers and advertisers.

\section{About India Currents}

The mission statement of the magazine India Currents states that,

India Currents is an important facet of America's emerging multicultural identity - a monthly publication devoted to the exploration of the heritage and culture of India as it exists in the United States. The magazine covers a wide range of subjectsopinion, music, dance, film, literature, travel, recipes, fiction, business-that are of interest to Indian Americans and Indophiles .... At the heart of the magazine is the most comprehensive calendar of Indian events in North America, used extensively by readers to plan their leisure and entertainment. (I 1)

The contributors to the magazine are almost exclusively of Indian origin, and the topics of the articles are also mostly Indian in focus. Major events in the US, like the general elections, are also covered in lead stories or editorials, but this is not the primary focus of the magazine.

The magazine has been in print since 1987 and is published in English. It is a free magazine and is distributed free in Indian grocery stores, restaurants, and such establishments. Therefore, it is probable that the increased population of Indian immigrants in the Bay Area, which frequents the local Indian shops and restaurants, would have access to the magazine. The staff also mails out copies to registered 
subscribers, but these are comparatively few in number. The circulation, therefore, reflects the available readership in the area.

The current circulation areas are: a) Northern California edition: (Bay Area) Santa Clara County, Alameda County, Contra Costa County, San Mateo County, and San Francisco; and b) Southern California edition: LA County, Orange County, San Bernardino County, Riverside County, and San Diego County.

The current circulation figures are: a) 20,600 for Northern California; and b) 12,000 for Southern California (Jethanandani, A., personal communication, April 5, 2005).

Ethnic media, to a great extent, seek their audience in the immigrant population. The India Currents Web site, in the page "About Us" states that: "Americans of all backgrounds are interested in learning about other world cultures, particularly Indian, and that they respond to information that is presented to them in an accessible and attractive manner." (I 2). However, the presence of an immigration department and visa dates on the website and the magazine is an indication of the target audience.

This magazine was chosen to be the subject of the study as it reflects many of the issues in the Indian immigrant acculturation process. For example, the magazine carries articles by Ranjani Nellore, an Indian immigrant who moved back to India after staying in the US for thirteen years. In one article she observes, "Over the years I noticed how this group (Indian immigrants) refers to India as 'back home,' while people of other races whose ancestors adopted America as their home refer to their country of origin as 'old country"” ( $\mathbb{2}$ 2). The ambivalence between the acceptance of the new and the holding on 
to the past and the overall immigrant experience are visible in the content of this magazine.

The Theory

Narrative Analysis

According to Riessman (1993), the underlying belief in narrative analysis is that narratives are told by the teller, for the following puposes:

1. To place their experiences in order.

2. Construct meaning of the events and actions in their lives.

3. Create their own self-representation or identity, to be understood by the reader.

4. Persuade the audience or the reader, though the same text may have different meanings for different readers.

The narrative texts are rarely complete representations of reality. According to Riessman (1993), narratives "are constructed, creatively authored, rhetorical, replete with assumptions and interpretive" (p. 5). Though the language used in narrative texts makes the experience real, the representation is consciously or unconsciously influenced by the effect desired on the audience. The text is also affected by how the narrator understands those events and the social context in which they are placed.

Riessman (1993) noted that, "narrative analysis takes as its object of investigation the story itself" (p. 1). The methodological approach in narrative analysis is to analyze the story to see:

How it is put together, the linguistic and cultural resources it draws on and how it persuades a listener of authenticity. Analysis in narrative studies opens up the forms of telling about the experience, not simply the content to which the language refers. (p. 2) 
The research challenge is to identify certain similarities, themes across the master narrative into an aggregate to understand why the story was told in that particular way. Riessman (1993) stressed that different genres of narrative, with appropriate styles and structures, are chosen by the teller based on their intentions and their audiences as distinctive genres have different persuasive effects on the reader.

According to Riessman (1993), "Narrative analysis identifies the basic story which is being told, focusing on the way an account or narrative is constructed, the intention of the teller and the nature of the audience as well as the meaning of the story or plot" (as cited in Ritchie \& Lewis, 2003, p. 42). Ritchie and Lewis also highlighted that narrative analysis focuses on the structure and construction of the text and can be used to qualitatively identify key themes, concepts, and categories in the selected data.

Narrative analysis has another important function; it can inform us about the latent content, subtexts, and about other factors influencing content, such as the social and political influences, the cultural influences, and values and ideologies of the narrator. According to Riessman (1993), "Studying narratives is additionally useful for what they reveal about social life—culture "speaks itself" through an individual's story" (p. 5). This kind of analysis is therefore very useful for studying communication texts with different levels of meaning. Berdayes and Berdayes (1998) agreed with this concept when they stressed that, "Narrative is important in constructing social reality. It defines a coherent world within which social action occurs. Narrative analysis offers a powerful tool for revealing assumptions that define social settings" (p. 1). 
Narrative analysis has been used for analyzing personal narratives, such as interviews, story-telling, myths, and narrative texts to study how the plots are constructed and how the narrator presents his or her view of reality. This method can be applied to journalistic articles as well. As Barnett (2005) explained, "Journalism is the art and practice of telling stories. Although news stories chronicle what happened today, storytelling is a centuries-old practice, a way to communicate facts, ideas, and beliefs" (p. 13). Barnett (2005) noted that journalists, to illustrate the story they are telling, use and thereby reinforce the cultural myths that are prevalent in society. She stressed that, "narrative analysis offers a useful and logical means to examine news articles and identify and deconstruct the myths embedded in news" (p. 14). She stated that the central elements of narrative: events, characters, temporal relationships and causal relationships mirror the journalistic questions of who, what, when, where, why, and how, which is why narrative analysis can be used to successfully study the content of news articles.

Framing Analysis

McQuail (2000) defined framing as “... a way of giving some interpretation to isolated items of fact" (p. 343). The theoretical background to framing, according to Scheufele (2000), lies in Heider's attribution theory which says that individuals try to make sense of the complexities of the world by attributing responsibilities of an observed behavior to a person. Iyengar (1996) agreed that responsibility is the concept that people build their understanding of social issues on and noted that "the concept of framing refers to the effects of presentation on judgment and choice" (p. 61). Iyengar also stressed that even the form and wording of survey questions can affect responses and that an 
individual's acculturation or worldview can influence the way he attributes responsibility. For the purpose of this study, framing analysis is used to see how the language patterns and cultural symbols used in the text are used to frame the content.

Entman (1993) pointed out that:

Framing essentially involves selection and salience. To frame is to select some aspects of a perceived reality and make them more salient in a communicating text, in such a way as to promote a particular problem definition, causal interpretation, moral evaluation, and/or treatment recommendation for the item described. (p. 52)

Entman (1993) stressed that frames define problems as caused by an agent, identify causes or forces, evaluate effects and suggest and justify treatments for the problems, and predict effects. The communicator, text, receiver, and the culture are identified as the four places in the communication process which contain frames. The communicators consciously or unconsciously decide what to say based on their frames of reference. The receivers interpret this communication based on their thinking processes or frames of reference. While these are not tangible, the text can be analyzed for the presence or absence of "certain keywords, stock phrases, stereotyped images, sources of information, and sentences that provide thematically reinforcing clusters of facts or judgements" (p. 52). And culture gives rises to the most commonly used set of frames, which Entman (1993) defined as the "empirically demonstrable set of common frames exhibited in the discourse and thinking of most people in a social grouping" (p. 53).

Culture is used to give salience to bits of information by associating them with culturally familiar symbols. This method of highlighting one aspect of reality also means that the receiver's attention is directed away from other issues. Entman (1993) noted that 
framing could be a valuable research paradigm to understand "the operation and outcomes of any particular system of thought and action" (p. 56) in race research and cultural studies.

Wilcox (2001) discussed that "the term framing was historically applied to journalists and editors and how they selected certain facts, themes, treatments and even words to frame a story that would generate maximum interest and understanding among readers and viewers" (p. 39). As the general reader may not have the specialized knowledge to comprehend all that they read or watch, the way any issue is portrayed by the media is generally accepted and rarely questioned; hence media are criticized for not being objective.

Gauntlet (2000) stressed that, "Information and ideas from the media do not merely reflect the social world, then, but contribute to its shape" (p. 98). Narratives carry value-systems and can limit the reader's acceptance to what is or is not accepted by society. Therefore, although presenting events on a certain frame of reference is often done to enhance interest and comprehension, very often it becomes the social reality. According to Korzenny and Schiff (1992), the reason for studying the media texts is: "We assume that the texts carried on the media reflect interesting things about the society (and country) in which they are created. We also assume that these texts affect their societies in various ways," (pp. 13-14). Korzenny and Schiff also state that it is the programs or the texts carried by the media that are of significance.

There is often a strong element of subjectivity and hidden cultural values in the way content is structured. McQuail (2000) stated that, "The standards of objectivity 
which are built into the news code are more likely to be expressed in the manner of handling and reporting events than in the selection or neutrality of presentation" (p. 343). McQuail stressed that to do any framing analysis, the content frame has to be compared with the frame of reference in the mind of an audience member, and the general effects of employing frames to communicate effectively with audience members.

In this study, framing analysis was used as part of analyzing the main narrative. The focus was on the assumptions embedded into the structure of the text, the cultural symbols emphasized, and the treatment of the immigrant and acculturation experience.

The narrative analysis method used in this study is similar to that followed by Berdayes and Berdayes (1998) in their article on, "The Information Superhighway in Contemporary Magazine Narrative." Berdayes and Berdayes isolate the following elements in their article, "settings, characters, narrator, temporal relations, causal relations, audience and themes" (p. 5). This was the broad outline that was followed in an attempt to answer the following research questions:

1. What are the main narratives that run through the content of the magazine?

2. Are symbols, frames, and patterns used in presentation of content in India Currents magazine to emphasize Indian heritage culture or the host culture?

3. How does the content present the immigrant experience and in what context, and how does it relate to the reader?

4. How is the identity of the immigrant portrayed? Is his involvement in the new host society or with events from his home country? 
5. Since the Indian immigrant population in the Bay Area has increased significantly between 1990 and 2000 , has the content changed in any way, reflecting the presumably available readership? 


\section{CHAPTER 3}

\section{THE METHOD}

Narrative analysis was felt to be the most suitable method for the object of enquiry: understanding the meta-story in the text. Analysis of the language, signs, and symbols used in the narrative to frame these stories, to appeal to the reader, was done. The frames used in the stories were analyzed to identify the way they appealed to the reader. Did they make him feel like a displaced Indian looking for some connection to his heritage culture or did they make him comfortable in the society he was in? The method utilized a combination of theories to study the themes in the stories appearing in India Currents magazine. "Magazines and self-help books ... tend to be more direct in talking about ways to live life-actively encouraging their readers to act like the confident and assertive characters, with clear goals, that we like to watch on screen" stressed Gauntlett (2000, p. 111). This relationship between the magazine and the reader was the premise of this study.

\section{Preliminary Research}

The editor of the magazine was approached for permission to access the archives as only issues of the past three years are available online. India Currents magazine was started in 1987 and is published monthly, except for a combined issue for the months of December and January. This researcher proposed to study issues of every other year since the publication of the magazine, that is, the odd years, from 1987 and to 1999 , and every year since 1999-which may be fairly noted as the year of greater Indian 
immigrant entry into the United States-till 2005. That led to a minimum of 138 issues. Also, the focus was on the editorial and the articles, not on the advertising. Basic Concepts

Korzenny and Schiff (1992) in their analysis of media texts from a cross-cultural perspective selected certain comprehensives themes to focus attention on. The following main concepts were adapted to align with the line of questioning of this study:

1. Values of the characters: What values are emphasized, and what values are attacked or neglected? What are the main social or political values that are highlighted? Do the American values of individualism and capitalism take precedence or are more community-oriented values reflected in the stories?

2. Social class and characteristics: Do the stories refer to the social class of the immigrants? What do the immigrants think of their position in the host society?

3. Dominant themes: What are the dominant themes? How do they relate to the immigrant or acculturation experience? What are the ideologies that are propagated?

4. Language and images: How does the language frame the text? How is it used to achieve a sense of immediacy and relevancy with the reader?

5. The meta-story: What is the master-narrative that flows through these texts with respect to the immigration experience?

There are three types of articles in India Currents magazine, based on their position on acculturation/immigration: 
1. Articles whose content/tone is obviously related to acculturation issues.

2. Articles whose content/tone is not obviously related to acculturation issues, but the acculturation/immigration experience is still an underlying theme.

3. Articles whose content is unrelated to acculturation issues.

The articles in India Currents can be grouped into different categories, depending on their focus: (a) Political Content, (b) Social Messages, (c) Cultural Values, (d) Topics of Local/transient Interest, and (e) Commentary or Opinion Pieces. The terms that indicated pro- or con-acculturation changed with regard to the content of the article. Based on Entman's (1993) theory of framing analysis that culture gives rise to the stock of commonly evoked frames, terms were selected to identify in the text. The focus was on the kind of cultural symbols used as frames of reference. It was theorized that in articles which invoke a sense of nostalgia for the home country, the cultural references are Indian and in those where the acculturation is at an appreciable level, the frames are rooted in the American tradition.

The categories of terms used were:

1. Home: what or where is home; where does the Indian immigrant community feel at home?

2. Roots: are the roots felt to be in India or do the articles talk about putting down roots here?

3. Society: if the author talks about society and its norms, which society is referred to, and what societal forces/pressures are at work here? 
4. Culture: which culture is emphasized? If there is a comparison, which is portrayed as being superior?

5. Traditions: are American traditions lauded or Indian traditions?

6. Lifestyle: with regard to different aspects such as food, religion, art, books, social activities, what is the content and tone of the articles?

7. Identity: what do the authors see themselves as, Indian or desi, which is an Indian language word meaning "from the home country," South Asian, or Indian American. Usage of the word desi would be important, as it would indicate language retention as well.

8. Immigration/Diaspora: does the content, tone or identity portray itself as being exclusively for immigrants or the Indian diaspora? Use of the words "immigrant" or "diaspora" would indicate a very low level on the acculturation scale.

9. Involvement: what is the level of involvement in American politics, government, traditions, etc., as opposed to distancing from it? A hot button here would be of an immigrant achieving the American dream, as opposed to Indian achievement.

This researcher also looked for the overall tone and meta-story to see how the Indian immigrant experience was portrayed, whether the overall picture was that of either of the following:

1. A displaced Indian immigrant struggling to keep culture and tradition alive in the Silicon Valley 
2. An immigrant who has a foot in both worlds and is straddling two cultures simultaneously

3. An immigrant who is fully involved with different aspects of American life, though acknowledging his Indian roots

The findings of the narrative analysis are discussed in the results section of the thesis. 


\section{CHAPTER 4}

\section{RESULTS AND DISCUSSION}

For the purpose of this research, the number of issues of India Currents magazine analyzed was 133 , accounting for some missing issues from the archives. The magazine from its inception in 1987 grew from a listing or directory of Indian cultural events in the Bay Area to a magazine covering political, social, and cultural events of interest to the Indian immigrant. Over the years, the number of pages, articles, and writers in the magazine has increased steadily, as has the readership. However, the presence of the same publisher and editor team over the years ensures that there has been no drastic change in the direction, tone, or focus of the magazine.

\section{Structure and Role of the Magazine}

In May 1987, the magazine length was 8 pages, and it grew to 32 pages by the end of the year. By 1989 , the number of pages had risen sharply to 70 , with the inclusion of content as well as advertising. The highlight of the magazine is the calendar, a comprehensive listing of all cultural events of interest to the Indian immigrant reader which take place in the Bay Area.

Over the years, the magazine has added new columns and features to its content, while some have been removed. The magazine's structure comprises of a main cover story with perhaps two or three other big stories. The other topics covered are News, Perspectives (including Letters to the Editor, Editorial, Analysis, and Forum), features on Arts and Entertainment (consisting of book, music, and movie reviews), and Lifestyle (offering travelogues, short fiction pieces, recipes, and other contributed pieces). There is 
also a calendar of events for the month, which has evolved over the years into three separate sections: cultural, spiritual, and yoga.

India Currents follows all five functions of a community newspaper as defined by Vishwanath and Arora (2000). It provides information to the Indian immigrant community, helps them assimilate by providing positive coverage about their activities, transmits the heritage culture, and is also a watchdog for social issues such as domestic violence and racial crimes.

\section{Frames Used}

The content of the magazine is mounted on sheer visual frames of Indian cultural symbols. This is very often seen in descriptive articles, such as "Reflections" (Gogula, 1993):

I remember the time when I was five years old and how I used to bathe in the backyard of the huge house we lived in... . The maid then lit the incense we called sambrani to dry my hair. As the smoke from the incense rose, I counted the mangoes in the trees. The smell of the incense filled the yard and through the smoke I could see sparrows hopping around. (p. 32)

The magazine's very purpose at its beginning was to highlight the Indian arts and cultural experiences available in the Bay Area: "India Currents concedes its goal has always been to encourage lovers of Indian culture to celebrate and share these artistic and cultural traditions joyously and openly," (Kumar, 1987b, p. 3). Even the different sections of the magazine that developed later, such as Sports, Fiction, Business and Politics focus exclusively on India. However, no negativity about any other culture is seen in the content of the magazine. 
From 1987 till 1993, the articles are mostly about Indian dance, music, and art. These are not treated in a simplistic way to educate and encourage the novice. Rather, they assume that the reader has some previous knowledge of the art form and is interested in learning more about it. But the artists reviewed are usually based in the Bay Area, and there is a duality in reading about the tradition of their art, and their struggle to propagate it in the new land.

The cover pages and cover stories are all about issues related to India or the Indian immigrant community. The news briefs (usually from Associated Press) are about events occurring in the Indian sub-continent or about events related to Indian immigrants in America, though the latter are minimal in the initial years. There is a feature on travel in each issue which is usually written by an Indian immigrant to the US visiting India. This is probably the most evocative of memories of India, with sights, sounds, and smells described, creating a mood of nostalgia.

The main focus of the magazine, which is announced in the editorial of the very first issue, is "an effort to provide accurate and timely information about such (cultural) events to the Indian community" (Kumar, 1987a, p.3). The calendar of cultural events in the community is one of the main features of the magazine and expands in later years. Indian culture is such a strong influence that even as late into the magazine's publication as January 1999, the editor discusses in the editorial that an image of a rock star, albeit an Indian one, on the cover, "elicited calls of shocked surprise from readers more accustomed to seeing classical dancers on the cover than a rock star" (Kumar, 1998 1999, p. 2). 
However, the exclusivity of Indian symbols declines after 1993 and there are more stories and articles about the lives of immigrants here. Descriptions of a university campus or a city apartment in the US intermingle with descriptions of India. This is also reinforced by stories of the second generation growing up here, which invariably have an American setting. But even in the stories of the second generation, there are the inevitable culture clashes between the older and the younger generation; stories in which symbols of Indian culture, such as dance, music, or worship play a role. But in the 2000s, as the narrative of the magazine changes, the frames change too. There are more descriptions of life in the United States, as in the article "Putting Down Roots" (RoyChowdhury, 2003a):

It looks like just another office park. The low slung brick building, the beds of cheery pansies, the skinny sidewalks in streets meant for cars rather than pedestrians, the gently curving sculptured grassy beds. But this is 2003 and there are quite a few 'For Lease' signs on the walls. But one of them is about to come down in Milpitas. ... the Indian community in the Bay Area is getting itself a spanking new community center. And with true Silicon Valley chutzpah, the India Community Center (ICC) is aiming big-at 20,000 sq. feet, it's the largest in the nation. (\$ 1)

\section{Narrative Analysis}

Rieseman noted that, "We use narratives to explain who we are, why events occur, how we act and respond, and what we value; consequently, narratives provide a mirror for social truths, although not always an exact record of truth" (Rieseman as cited in Bennet, 1993, p. 13).

The fact that the Indian immigrant is highly educated and culturally-oriented is obvious when we read articles on the immigrant experience in India Currents magazine. These articles are usually written by first and second generation immigrants who are well 
aware of the choice they have made in moving to America. Although they may have deep emotional feelings about their life here or life in India, they are able to examine and understand their experience, though they may not always be able to make peace with reality. Their actions and responses, as evidenced by the stories in India Currents show that even after living in the United States for many years, they are acutely and emotionally involved with Indian culture and traditions.

India Currents encourages discussion on all issues on interest to the Indian immigrant. "The community is strengthened, not weakened, by open discussion," says the editor as he calls for Indian Americans to be more participative in their community and become media-literate (Kumar, 2000b, p. 2). By addressing issues that affect the Indian American community and by publishing the letters sent in by readers, India Currents becomes a forum for public discussion in the Indian immigrant community. It creates a sense of an imagined community as the stories in the magazine are by, for, and about the lives of Indian immigrants in America.

The acculturation experiences in the narratives in this magazine are visibly different over the years. This study classifies them chronologically. 1987-1993.

Acculturation. After the change in immigration laws in the year 1965, the US was open to Indian immigrants, but the first Indian immigrants arrived in a country which was unconnected to their land of origin, and where their heritage culture was radically different from the host culture. This produced severe acculturation stress for the first generation, which is explored in articles such as "Facing a New Reality" (Pandya, 1987). 
"There are problems for Indian immigrants because of an almost complete transposition of values of an old society on a new and modern culture, which has neither the need nor the respect for these values" says Dr. Patel, a psychiatrist who is quoted in the article (Pandya, p. 10). The women, in this article, "surrounded though they are by all the symbols of luxury, live with a strange sense of loss, of deprivation, and a romantic, almost pathetic nostalgia for India" states the article ending with a quote by one of the women that, "I have been wanting to go back ever since we came fifteen years ago. I have told my husband that I only need 24 hours to pack. I am ready to leave whenever he is," (Pandya, p. 11).

This attitude creates conflict with the second generation. The article, "Growing Up in America," finds that "Many adults view themselves primarily as Indians who happen to live in America, whereas most children view themselves as Americans with Indian parents and strange customs and accents" (Vepa, 1993, p. 18). The second generation is often confused and tom between the polar cultures of their heritage and the country they are living in. One second generation Indian-American writes in "Proud to be an Indian" that, "I hated my culture so much that at one time I started telling everyone I was Mexican" (Anonymous, 1993, p. 3).

Identity formation. Names form an important part of identity and the issue of Indian names being changed to more familiar American names is one that is raised many times during these years. Greater acceptance in the new society is cited as the reason for the change. The article, "Cosmetic Change" (Bhatia, 1993) points out the existence of racial discrimination, and states, "One who has not experienced it (discrimination) cannot 
possibly know the feeling of being identified as a 'foreigner' - and cast in all the stereotypes that accompany it—without ever being introduced as one" (Bhatia, p. M5). However, the writer insists that "to change it (name) that I might 'succeed' would be to deny my own existence" (Bhatia, p. M5). The editorial concurs that "in giving up our Indian names, we are losing a deep and subtle part of our identity" (Kumar, 1989b, p. 3).

Many articles seek to establish a distinct identity, and distinguish the Indian immigrant from the Native American Indian. One such example is an editorial, "Call me anything but" (Kumar, 1987c, p. 3), which notes that:

As an Indian, I feel the need to point out that there is only one India . . . so also, there is only one kind of Indian, the kind that comes from India. . . qualifying my name with "East" or "Asian" makes me feel as if I am less of an Indian. (p. 5)

The label of exotic Indians, is also not accepted and the editor insists that its usage is "the inability of people to relate to and understand others from a different culture," (Kumar, 1989a, p. 3). There is a strong emphasis on retaining the Indian identity at this period; "What does it mean to become American? It doesn't mean that you stop being Indian," (Divakaruni, 1991, p. 19). There are also stories on the history of the earliest immigrants to this country, such as, "The Mexican-Hindu Connection-Mexican Indians Search for Their Roots" (Pinsky, 1989) and "From India to America-The Story of Indian Immigration" (Chandrasekhar, 1991).

Clearing up misconceptions about the Indian immigrant community is also part of building the new identity and India Currents features articles exhorting Indian immigrant readers to protest against misrepresentation of India in programs by television stations that are "continuing to portray non-European cultures as exotic, strange, alien, and 
bizarre. This might attract viewers but won't inform them. India Currents urges readers to "watch the program and send comments to KTEH" (Cultural Zoo, 1987, p. 7).

Cultural retention. The heritage culture is an important component of identity, and there is a strong inclination towards retention. "Appreciate the richness of your culture, share it with others. Don't wish to be something you are not ... learn all you can about your culture and its history, so you can educate others, so you won't forget" says Tandon (1993). Language being a valuable carrier of culture, the editorial encourages immigrants to pass on their language to their children, when it asks, "Does it not make sense for the Indian-American child to have the option of studying Hindi, Tamil, Bangla or Sanskrit?" (Kumar, 1989d, p. 5). Stories in this period usually end with a renewed appreciation for the heritage culture or at least encouragement to achieving a balance between the two cultures. The article, "Quantum Healer" (Thakran, 1991) notes, They (Indian community in America) should assimilate into the mainstream, but they should maintain their cultural identity, as a lot of other people have done. We should be a part of this country because it's as much our country as anyone else's, but we should maintain our cultural identity because there is a lot of strength in that. (p. 23)

Identification with other minorities. The magazine at this stage also includes articles about other South Asian countries, such as "College Days in Pakistan" (Javaid Qazi, 1989), and there is also a demand by some readers to label India Currents as South Asian Currents. The editor considers this idea as he argues the case for including articles about Pakistan and Bangladesh; "As neighbors, we share history, ancestry, language, culture" (Kumar, 1989c, p. 5). 
The magazine also associates the Indian immigrant community with other minorities in editorials such as, "A Kinder, Gentler Police-Why Indian Americans Must be Involved" (Kumar, 1991). This article insists that, "We, too, are part of the larger Asian American community, and the still larger minority community. Prevailing stereotypes about Asians and other minorities affect us no less ..." (Kumar, p. 7).

Community orientation. There are also stories addressing Indian Americans as a group for community activities such as blood donation, working for peace etc. as well as to work on behalf of the home country. Nagarajan (1993) calls on the Indian American community to "explore our role for promoting the Indian cause in the U.S." (p. 6). This appeal for the community to become more aware and participative is seen at times of trouble-whether in the US at times of racial discrimination or in India during the communal riots.

For example, in the late eighties and early nineties, The Dot Busters was a group in New Jersey which targeted the local Indian immigrant community with racial harassment. This is reflected in the articles about racial crimes that appear in India Currents in the early 1990s, such as, "Case Closed" (Banerjee, 1993) which talks about the death of UNLV student Srinivas Chirukuri. This article asks readers to send letters requesting that the case of Srinivas Chirukuri's death be reopened and thoroughly investigated at the state and local levels.

To understand the new society, articles also educate readers about how the Indian immigrant community is perceived. The article "The Faces of Racism" contains interviews of natives of New Jersey who insist, "If they (Indian immigrants) wanna stay 
here, they should, like, live the way we live," (Eye on Asia and Asian American Legal Defense and Education Fund, 1993, pp. 18 -19) and there are also articles highlighting the ways the Indian immigrant community is working on these issues.

The unity of the Indian immigrant community is also reinforced in the aftermath of the communal riots in India in 1993 with stories such as "Indian Americans Horrified" (Harry Stern, 1993), and "Indians Rally Against Communalism" (Kaul, 1993). The latter reports that in one of the rallies covered, Indian immigrants “. . condemned the demolition of the Babri Mosque, and called on all secular forces to wake up and unite against the menace of communalism that is destroying the fabric of the Indian republic" (Kaul, 1993, p. M13). This issue is also the subject of many letters to the editor, with one writer even urging the immigrant community to take a pledge for communal harmony, "I am no longer satisfied with my own effort to prevent what has been happening among us in South Asia and elsewhere. ... I need to do something more" (Rohila, 1993, p. 4). Considering the fact that the immigrant community is far from its homeland, this reveals the strong emotions amongst the immigrants for the home country. Other events of interest to the community, such as the installation of the Chair in India Studies at Berkeley University are also covered with much interest, with writers arguing for and against it, in articles such as "India Studies: By Whom? For Whom?" (Vatunk, 1991), and it is also the subject of many letters to the editor.

The location of home. As the community grapples with challenges in the adopted land, they are still unsure about where their home is. Articles such as "Looking for Home" (Roy-Chowdhury, 1993a) explore what home means to the immigrant. "And 
where is home? In a no man's or woman's land between two cultures?"( Roy-

Chowdhury, p. C12) is the question asked.

In 1989, we see a small feature "Word from Home" which gives the etymology of words of Indian origin (Gupta, 1991); an indicator the magazine still associates the word 'home' with India. This is also seen in contributed articles such as, "A Journey Home" (Narula, 1993), in which a second generation Indian American writes about bathing in the Ganges, "I felt something I had never felt before, I was home" (Narula, p. C73).

Since home is in India, the next concern "To Stay or Not to Stay" (Srinivasan \& Loka, 1993) is discussed in a forum about Indian Americans should staying on in the United States. Both the parties agree that they would like to eventually return to India, the only question being what would be the right time for the eventual return.

But while they are here, cinema provides an important link to India. Till 1993, the emphasis is on the arts, crafts, Indian classical dance, music, and poetry reviews, and very little on entertainment. The appeal is to the intellectual Indian with articles such as "The Flowering of Chhandam" (Zonka, 1993). Naz Cinema theatres, showing Indian movies, open in the Bay Area in 1993 (Kumar, 1993), and this causes the shift of the focus to commercial cinema. The magazine in 1993 starts listing the availability of Indian movies and movie stars in the Bay Area, and starts moving away from its focus on art and parallel cinema to the commercial movies, as is seen in "Bachchanalian Riots" (Ganguly, 1993).

Indian films portray a magic realism that transports every Indian into a world that they know does not exist, but desperately believe in. For immigrant Indians, this magic realism is the umbilical cord to their earth, mother, nation, state that exists first and foremost in their minds. (p. C10) 
Feedback from readers. India Currents' focus is appreciated by the Indian community, as evidenced by a letter to the editor, "Through your paper, I feel part of the community, and in Texas, that's important, we're so cut off here" (Vaid, 1987).

However, the pro-Indian content is not always appreciated; one reader writes in a letter to the editor, "It seems that many of the articles and letters in your magazine are either by Indians outraged at one thing or another in America or by Americans obsequiously praising everything Indian and apologizing for everything American or Western" (Mirton, 1991, p.10). The writer concludes that "so many of your Indian writers and readers are disgusted with life in America" (Mirton, p.10).

Topics covered by the magazine. In 1991, the important features are the "News Roundup", a single page news capsule of latest happenings in the sub-continent with the focus on India and "Public Eye" focusing on Indian immigrants in the Bay Area who have achieved some measure of success or fame in their chosen activity. There is little coverage of any events, national or local, which had occurred in the US at that time.

There is also a forum for immigration issues which directly addresses immigration formalities and procedures, which is of relevance to the immigrant. In 1990, the magazine starts distributing two editions-one for Northern California and one for Southern California - with a paid subscription offering a sleeker version of the magazine in 1992. This however, is later discontinued, and the magazine continues to be distributed free.

Cartoons about Indian immigrant life in the US start in 1993 and die out in the late 1990's after a succession of artists and characters. The word desi, meaning 'of the 
home country' makes its appearance in the December 1993 issue, (Roy-Chowdhury, 1993b). Most of the stories are by Indian immigrant writers, with the news features from Associated Press. There are stories by non-Indian writers or about non-Indian artists or celebrities, but they are always about how much these artists or celebrities appreciate the different facets of Indian culture.

The magazine at this time has the most coverage about Indian spiritual readers and artists in the Bay Area. Considering the fact that most of the celebrities advertise in the magazine as well, it is hard to say how objective the magazine's reviews could be; there is generally no negative review. There are also plenty of stories which exhort Indian Americans to be more participative in American society, and also to give back to India. 1995-1999.

Changing Focus. We see the focus of the magazine change. As India Currents celebrates ten years of its publication, it promises in the publisher's note to deliver "articles on Indian American lifestyles, business, software, politics, spirituality, food, films, arts, literature and travel... Through the editorial, letters and opinion columns, we will continue to present our unique Indian American perspective." (Jethanandani, 1996-1997, p. 3, s/b 6).

Coverage of Silicon Valley entrepreneurs. Articles such as "Milpitas Mayor Proclaims IBPW day" (Grover, 1995b) sees the magazine rejoice in the community's success in Silicon Valley. In 1997, there are a number of stories about Indian entrepreneurs in Silicon Valley, such as "Indians in cyberspace" (Melvani, 1997), and "Dollars and Sense - the Vivek Ranadive story" (Ramanathan, 1997). The article "Indians behind the Internet" 
(Sreenivas,1997) states that "Indian-Americans are at the very forefront of promoting companies or are leading them by the dozen in the world of cyberspace," and in the article "That will be a dollar for 10 million bits," even a stereotype of a Silicon Valley Indian immigrant is presented (Ramanathan, 1997).

Community participation. In this period, articles such as "Youth at Risk" (Grover, 1995a), highlight the Indian immigrant community's awareness and local participation. Immigrants are now taking an active part in the community, notes the magazine adding that "The image of the wealthy Silicon Valley Indian entrepreneur, who cares little for his or her community has forever been shattered" (Kumar, 1995, p.C50). The editorial concurs; "Indian immigrants learn from America everyday of their lives. But the signs that they give back in equal measure are also all around us" (Kumar, 1997, p. 4).

Immigrants are also working on issues specific to their community, points out the article "Finger on the Pulse - A South Asian Perspective on Public Health Issues", (Seeram, 1995) which highlights a television program showcasing "family problems, cultural diversity, gang violence, identity crisis, raging hormones, self esteem, and the school environment" (Seeram, p. 7).

To attain greater visibility, the magazine also publishes an article on accessing the western media, "as the Indian-American community in the Bay Area-and the countrygrows, to have some degree of success it will have to learn a few basic rules about dealing with the media" (Winokur, 1995, p.7).

Culture, identity, and home. The main focus is still on Indian culture. Apart from the regular coverage, there are also stories by non-Indians extolling India. In the article 
"Like a Lover" (Singh, 1997), Robert Bly, a translator of Indian poetry talks about what "the west might learn from India" (Singh, p. 56), and in the article, "A Certain Innocence" filmmaker Michael Tobias describes his fascination with India (Kimani, 1997).

However, in the stories in this period, the issues and concerns addressed overlap between events of interest in America and Indian symbols with an easy familiarity. For example, in the article "Is True Partnership Possible?" (Sarvate, December 1996 - January 1997), though the reference point at the beginning of the story is the O. J. Simpson case, the writer talks about Indian men, worship, hindu rituals, and blessings in Sanskrit, with no translation or explanation for the Sanskrit prayer.

These bicultural references possibly due to the fact that by 1999 , there is also greater visibility of Indian culture in the popular culture, which the magazine highlights through articles such as "Art: Where Inner and Outer Worlds Collide" (Sitaraman, 1999) and "All the World's a Stage," which is about South Asian theatre actors (Roy-Chowdhury, 1999). But there is also uneasiness at the west's adoption of Indian culture in articles such as "Brownsploitation" which asks the question on the cover "Are we witnessing the mainstreaming of Indian culture or more cultural imperialism?" (Malhotra-Singh, 1999).

The influence of western culture in India as seen in the newer immigrants is also felt in the community in the Bay Area (Kumar, March 1999):

"Over the last five years, the face of the Indian community in the San Francisco Bay Area has undergone a remarkable transition... . Two out of five engineers coming into the U.S. are from India. ... Their assimilation into this society seems rapid and effortless ... what culture shock can America give to a generation raised on MTV? ... In coming issues, we want to be able to see the Silicon Valley, the U.S., and the world through your eyes ..." (p. 3). 
Indian immigrant fiction is coming into its own at this time and book reviews talk about, "the experiences we have faced as refugees or living in exile" (Sanzgiri, 1997). The article "Search for Identity - the Myth and the Reality of the Diasporic Woman" explains "the problem of identity within the Indian-American community in an environment of not only inter-racial conflicts but also intergenerational problems" (Mani, 1998 - 1999, p. 84).

However, the acculturation of the Indian immigrant community has started, and the editorial (Kumar, 1997) notes this change:

In the process, we have been transformed, and now some of us are even beginning to transform our environment. Some of us ... have embraced America ... some of us have become more Indian than we were when we left India. America has made us conscious of our Indian heritage in a way that India never did. . . It is not until you leave home that you appreciate how terrific Mom's cooking really was. (p. 4)

Yet, the anti-American perception of India Currents in the minds of some of its readers such as Rogers (1995) persists:

Generally I find India Currents editorials anti-American ... to a point that makes me wonder if you were dragged to this great land kicking and screaming against your will, or your very waking moment(s) in this country had been subjected to unspeakable torture, discrimination and condemnation on a daily basis. (p. 5)

Ties to India. Many travel articles in 1995 are by non-Indian contributors writing about their travel experiences in India, such as 'Where there is noise, there is life' (Colson, 1995). The first article about travel to a place other than India-Amsterdam — is published in 1995, and this first shift away from the exclusive coverage on India will lead to travel stories about other parts of the world in later issues. In 1997, the magazine has become aware of the Indian immigrant's place in American society and we find the word model minority being used. 
The opening up of the Indian economy in this period raises strong feeling both for and against such a development in articles such as, "Destination India" (Sreenivas, 1997). While the arguments raise some economic issues, there is an overall tentativeness, which is unusual. One might expect that the immigrants, who have left India to seek a better life for themselves, would feel positive about the possible globalization of their country. This uneasiness about changes in India is also seen in the articles covering the success in international beauty pageants by contestants from India. This could be due to those who have been here for a long time carrying a romanticized picture of the land they left behind realizing that the home country is changing. 2000-2005.

Local involvement and community awareness. In this period, India Currents encourages the community's involvement in American political affairs. The editorial points out that, "our increasing numbers may outpace our rate of assimilation into American society. ... Society at large needs us just as much as the workplace" (Kumar, 2000a, p. 3). There are a number of articles about American political affairs, such as, "President Bush" (Banerjee, 2001a), "Elections Serve as Right to Passage" (Sarvate, 2001a), and "It is long past the time for the Clintons to say adieu" (Sarvate, 2001b) in the magazine and from 2001 onwards, American political affairs become a recurring topic in the editorial.

There is also greater awareness about the community and an ability to look at inwards for strengths and weaknesses as in the article, "The 2000 Census and the Indian American community" (Banerjee, August 2001b): 
Indian Americans are very unusual amongst ethnic communities in the US. One becomes a member of other ethnic groups mostly by being born (into them). Most IndianAmericans have attained their label through doing well in school in India. This has made Indian Americans privileged elites in both Indian and American societies. (p. 36)

While the achievements of the community are lauded in articles such as, "Indian-Americans of the Century" (Gopikrishna \& Kumar, 1999 December- 2000 January), India Currents also focuses on the plight of Indian immigrant workers who labor at low-paying assembly and manufacturing jobs in "Breaking the Model Minority Myth" (Jayadev, 2000). Articles such as, "Indians in the North-American Political System" (Srinivasan \& Loka, 2000) discuss whether Indian immigrants are finally becoming visible in the political mainstream.

The second generation. Stories about the new generation labeled American Born Confused Desi or ABCD (Chawda, 2001), come into focus, with many book reviews of immigrant fiction (Mani, 2001), and short pieces of fiction written by the second generation growing up in the Bay Area, featured in the magazine.

Articles such as, "Dancing Lessons" (Srinivasan, 2001) note that though the second generation may have the best of both worlds-a strong indigenous culture and the material prosperity of the US - the pressure by their parents to keep the tradition alive can be tremendous. In contrast, stories such as "The Detached Desi" (Shah, 2004) are by second-generation Indian Americans searching for their roots. However, most secondgeneration immigrants talk about achieving a balance when they state that "by adopting the progressive values of the country you have befriended, you are able to effectively root out the ills in your own culture and graft it with the good in another" (Thiagarajan, 2004). The heritage culture is highlighted as a key part of the identity of the new generation; "the most 
precious wealth we can inherit is the cultural heritage and knowledge that makes us who we are, no matter which country or culture we actually live in" (Sanzgiri, 2001).

Acculturation experiences. Multiple acculturation experiences run in a parallel manner in this period. While there are stories about the second generation trying to achieve a balance between two cultures, stories such as "The Door" (Sharma, 2001) highlight the plight of those immigrants who have completely retained their heritage and have never ventured to acculturate in their adoptive country.

There are also stories about the new immigrants who land on US shores, and have a comparatively easier time, as there is already a strong community of Indian immigrants here who can help them to navigate the new environment. On the whole, points out the article "The 2000 Census and the Indian American Community" (Banerjee, 2001b), "Indian Americans are successful, non-aggressive, but unassimilated." (Banerjee, p. 38).

In this period, India Currents also features stories about immigrants who move back to India, and thus undergo a kind of re-acculturation as they try to adjust to the country which is no longer the one they remember (Sitaraman, 2001). Additionally, there are stories about the older generation, parents of the Indian immigrants who are settled here, as they grapple with the new environment, society and customs (Roy-Chowdury, 2003).

There is an awareness of the many problems that an immigrant has to face and an acknowledgement that no two Indian immigrant experiences can ever be entirely alike. Sharma (2002) lists the many distinct features of being an Indian immigrant in America. Sharma notes that for new immigrants, there is both euphoria and culture-shock upon arrival in the new land, both of which continue to affect immigrants even after years; but it 
is the lack of a support system, that hits new immigrants especially hard. She points out that like most other immigrant communities the Indian immigrant community stays closeknit. This is because of two reasons, the fear of the unknown and the lack of common ground between themselves and other ethnic communities.

Sharma (2002) also states that there are different types of immigrants: the first generation which adapts externally, yet clings to traditions emotionally; the second generation which is searching for its identity, caught between the differing cultures at home and outside; and the fresh-off-the-boat (FOB) immigrant, who eventually starts acculturating.

At this time, the psychological issues arising from acculturation start being featured. Articles such as "Honoring the East and the West" (Amlani, 2000) discuss the issues for "people who have roots in vastly different cultures (and) are involved in keeping their traditions and heritage, while changing their way of life to assimilate the new culture" (Amlani, p. 46). There eventually starts a monthly column on psychological issues of this nature hosted by the same writer from May 2000.

Location of Home. Till 2002, Indian immigrants still long for home, home primarily being India and they strive to keep the bonds to the motherland intact; "you cannot feel completely at home away from home" (Sharma, 2002). Cinema is a great rejuvenator of this bond, while a visit back home, may actually provide disillusionment to those caught in a time-warped ideal of the India they had left behind. For example, in the article by Seetaraman, (2002) "We all miss home" is the quote in the last paragraph, where home refers to the home they have left behind in Santa Clara. 
This acceptance of the new home in the US is now beginning to be seen in the features. The October issue of 2002 is a good example of this feeling of acceptance running though. In October 2002, the cover story is "Being Brown in America" (Roy-Chowdhury, 2002) which explores the influence of stricter immigration laws over the mass hysteria following the terrorist bombings on $9 / 11$. Though there are stories about unfair discrimination against those with brown skin, "in the midst of discrimination, there is hope. The new California Media-USC Annenberg poll found that even as they felt more insecure about their lives, immigrants in California felt overwhelmingly American," (Halperin, 2003).

Also, in the same month there is an article about the influx of Indian themes, directors and actors into Hollywood, "Signing in Hollywood" (Chawda, 2002c). From 2002, there is again a focus on successful Indian Americans in America. After 9/11, and with the beginning of the Iraq war, the writings begin to focus slowly on happenings in America, with more discussion in the forum on American policy, and more coverage in the letters to the editor.

From 2003 to 2005, the turmoil, angst and confusion in the immigrant voices have reduced. There is greater identification with the new country and the reasons could be: greater numbers of Indian immigrants in the Bay Area making the community a distinct and visible one; greater assimilation, with Indian immigrants running for city councils and other positions in office; and a greater visibility of Indians immigrants in America because of their appearing in commercial cinema, as noted in the articles "Something 
About Mira," (Chawda, 2002a) and "The Dashing Director, Ismail Merchant" (Chawda, 2002b).

We also begin to see the term "Indian -American" being used frequently, or the phrase "American of Indian origin." In the article "Indian Word Curry" (May 2003) India is not referred to as "back home" as the earlier feature "Word from Home" (Gupta, 1991) did. "What I am really trying to say is that I care about America" (Roy-Chowdhury, 2003b) is the confession that is made in this time, as even a writer who has been critical of American policy finds himself feeling at home in America.

From 2003, the magazine has been published online. Readers are encouraged to post their comments in the Website, and thus the discussion of the issues continues within the community of India Currents readers.

The direction the magazine plans to take is given in the article "Evolutions" (Nitya Ramanan, 2005):

As our immigrant community has come of age, we no longer feel threatened by the cultures of our adopted home... The magazine's content has also evolved to include not only Karnatik and Hindustani music, and classical dances from India, but also a fusion of modern and traditional, East and West. Today, India Currents reflects the state and perspectives of an eclectic readership. (T 4)

Some Trends Observed Over the Years There is a gradual moving away from the initial focus on arts towards lifestyle. In the late 1980's and the early 1990's, since the number of Indians was small, the Indian immigrant community tried to bond together with other South Asians, especially those from Pakistan and Bangladesh. These countries share a border with India, and are close culturally. In the middle 1990s, with the entry of more Indian immigrants into the Bay Area, this kind of grouping by association is not seen much more in the magazine; maybe was not found necessary. 
As a comparison of how much attitudes have changed, we can compare the call to change Indian first names. While the earlier article "Cosmetic Change" (Bhatia, 1993) was very emotional about the issue, the article, "What's in a name?" (Raman, 2002) considers the same issue as an inconvenience of living abroad and ventures the belief that in a few years, "pronouncing Indian names will be as easy an simple as any other name" (Raman, p. 38).

Earlier, the magazine featured more articles highlighting Indian culture, and even if the commercial media made mistakes about Indian history, there was an immediate call to arms to rectify this. But now, the Indian community has become aware of its worth and its flaws. Even the Recipe section is reflective of such change. While earlier recipes talked about traditional recipes, in the 2000 s we see recipes incorporating easily available local dishes such as pita bread in the recipe.

While the general tone and content of the magazine has stayed the same over the years, we can see a certain level of acculturation making the Indian American community palpably more comfortable in their environment as they slowly try to find a place for themselves in the new society. There is a good deal of coverage about events of interest in India in the early years, with very passionate reporting on societal ills. However, over the years, there is an increase in coverage of the issues in American society, and the problems faced by Indians as a group in America. This evolution of the magazine has probably helped it keep pace with its target audience. 
Results of the Analysis of Selected Terms

The different categories of terms were analyzed in the content of the magazine and the results are presented here. The researcher calculated the total number of times these terms occurred in the content. Then the percentage of times these words referred to a determining characteristic, were calculated.

The words and phrases that were used as indicators for the level of acculturation such as home, roots and society are shown in Table 1, Table 2, and Table 3 (p. 62). There is also an increasing awareness of the culture and traditions of the new country as seen in Table 4, and Table 5 (p. 63). These terms see a steady increase in usage to indicate a greater identification with America, an interest in the society, culture, tradition, lifestyle and a feeling of being at home and putting down roots here. The lifestyle content in the magazine, as seen in Table 6 (p. 63), moves away from focusing on India, as there is more participation and involvement with local issues.

The usage of words referring to the immigration/diaspora, shown in Table 7 (p. 64) is a little more ambivalent. It is only in the year 2000 onwards, that the usage of this word has decreased. The feeling of being an immigrant is still retained, though it may be with pride. However, we see a distinct new identity - that as an Indian Americanemerge as the strongest, as shown in Table 9 (p. 64). The maximum interest and involvement is in national and local affairs as shown in Table 8 (p. 64). 
Table 1

Results for term 'Home'

$\begin{array}{llll}\text { Year } & \text { India } & \text { America } & \text { Do not know }\end{array}$

\begin{tabular}{lllll}
$1987-1993$ & $67 \%$ & $8 \%$ & $25 \%$ & $12(100 \%)$ \\
$1995-1999$ & $50 \%$ & $50 \%$ & $0 \%$ & $4(100 \%)$ \\
$2000-2005$ & $47 \%$ & $53 \%$ & $0 \%$ & $17(100 \%)$ \\
\hline
\end{tabular}

Table 2

Results for term 'Roots'

Year India $\quad$ America $\quad$ Total

$\begin{array}{llll}1987-1993 & 89 \% & 11 \% & 9(100 \%)\end{array}$

$\begin{array}{llll}1995-1999 & 100 \% & 0 \% & 8(100 \%)\end{array}$

\begin{tabular}{llll}
$2000-2005$ & $71 \%$ & $29 \%$ & $7(100 \%)$ \\
\hline
\end{tabular}

Table 3

Results for term 'Society'

$\begin{array}{llll}\text { Year } & \text { India } & \text { America } & \text { Bay Area }\end{array}$

1987-1993

$11 \%$

$31 \%$

$58 \%$

$29(100 \%)$

1995-1999

$13 \%$

$32 \%$

$55 \%$

$47(100 \%)$

2000-2005

$14 \%$

$34 \%$

$52 \%$

$10(100 \%)$ 
Table 4

Results for term 'Culture'

\begin{tabular}{lrrrr} 
Year & India & America & Bay Area & Total \\
\hline $1987-1993$ & $90 \%$ & $6 \%$ & $4 \%$ & $52(100 \%)$ \\
$1995-1999$ & $93 \%$ & $7 \%$ & $0 \%$ & $45(100 \%)$ \\
$2000-2005$ & $88 \%$ & $12 \%$ & $0 \%$ & $32(100 \%)$ \\
\hline
\end{tabular}

Table 5

$\underline{\text { Results for term 'Tradition' }}$

$\begin{array}{llll}\text { Year } & \text { India } & \text { America } & \text { Total }\end{array}$

$\begin{array}{llll}1987-1993 & 100 \% & 0 \% & 27(100 \%)\end{array}$

$\begin{array}{llll}1995-1999 & 96 \% & 4 \% & 26(100 \%)\end{array}$

\begin{tabular}{llll}
$2000-2005$ & $93 \%$ & $7 \%$ & $15(100 \%)$ \\
\hline
\end{tabular}

Table 6

$\underline{\text { Results for term 'Lifestyle' }}$

\begin{tabular}{ccccr} 
Year & India & America & Bay Area & Total \\
\hline $1987-1993$ & $28 \%$ & $0 \%$ & $72 \%$ & $40(100 \%)$ \\
$1995-1999$ & $25 \%$ & $8 \%$ & $67 \%$ & $73(100 \%)$ \\
$2000-2005$ & $7 \%$ & $22 \%$ & $71 \%$ & $54(100 \%)$ \\
\hline
\end{tabular}


Table 7

Results for term 'Immigrant'

\begin{tabular}{ccc} 
Year & Average/Issue & Total \\
\hline $1987-1993$ & 0.76 & 32 \\
$1995-1999$ & 0.80 & 29 \\
$2000-2005$ & 0.68 & 47 \\
\hline
\end{tabular}

Table 8

$\underline{\text { Results for term 'Involvement' }}$

\begin{tabular}{ccccc} 
Year & India & America & Bay Area & Total \\
\hline $1987-1993$ & $9 \%$ & $10 \%$ & $81 \%$ & $58(100 \%)$ \\
$1995-1999$ & $11 \%$ & $19 \%$ & $70 \%$ & $54(100 \%)$ \\
$2000-2005$ & $6 \%$ & $61 \%$ & $33 \%$ & $34(100 \%)$ \\
\hline
\end{tabular}

Table 9

$\underline{\text { Results for term 'Identity' }}$

Year Indian American Indian-American South-Asian Total

\begin{tabular}{rrrrrr}
$1987-1993$ & $48 \%$ & $8 \%$ & $36 \%$ & $8 \%$ & $131(100 \%)$ \\
$1995-1999$ & $45 \%$ & $7 \%$ & $26 \%$ & $23 \%$ & $133(100 \%)$ \\
$2000-2005$ & $28 \%$ & $10 \%$ & $40 \%$ & $22 \%$ & $86(100 \%)$ \\
\hline
\end{tabular}




\section{CHAPTER 5}

\section{CONCLUSIONS}

India Currents magazine was started, is published, and continues to be read by Indian immigrants to the Bay Area, California. This makes the magazine a very good medium for carrying the community's voice. Since it is distributed free, it presumably has equal access to all Indian immigrants. Through letters to the editor and articles contributed by immigrants, it creates a sense of imagined community. The magazine's primary goal is to provide the Indian community with information about cultural events of interest to Indian immigrants that take place throughout the Bay Area thus fostering greater activity in cultural activities and community participation.

Narrative analysis shows that the magazine follows all the five primary functions of an immigrant media:

1. Provides information about events back in the homeland

2. Provides positive coverage about the activities of immigrants in the new country

3. Provides information about cultural and community-oriented local activities

4. Provides information about immigration-related affairs and events affecting the immigrant community as a whole

5. Boosts the community in the public eye by portraying the immigrant community in a favorable light

Though immigrant media generally prefer not to focus on conflict reporting about the immigrant community (Vishwanath \& Arora, 2000), India Currents does not always 
project the Indian immigrant community as a model minority. It also discusses issues such as domestic violence, gay and lesbian affairs, and issues concerning the underprivileged in the community.

Framing analysis reveals that the magazine, which was initially started to provide information about cultural and community-oriented activities to the local immigrants, emphasizes strongly on Indian culture. Reviews of books, performances, concerts and exhibitions, with timings of upcoming events are the main focus of the magazine. While in the initial years of the magazine the frames were very strongly Indian, over the years one sees a decline in this direction. In the 2000 s, the focus of the magazine has also changed to include articles to life and living in the Bay Area and so the frames and descriptions change. While the Indian influence is still present, it is now diluted and becomes a hybrid of Indian culture and life in the Bay Area. As the magazine is primarily aimed towards its readers in California, there is in later years, a great many descriptions of the local community and coverage of local activities.

Narrative analysis of the voices of the immigrant in the early years of the magazine revealed that in the community here was still a primary identification as 'Indian,' with great involvement in events happening in India, even if the community here was effectually able to do little. There was intense reporting of events occurring in India and little or no coverage of the events occurring in the United States, except when they directly affected the immigrant community. The usage of selected terms which was examined, show that in the narratives "India" was mostly referred to as home, and there was also some confusion as to where home really was. 
But this changed in the mid-1990s as the Bay Area saw the emergence of many Silicon Valley entrepreneurs of Indian origin. The magazine celebrates their success with many articles focusing on the success of Indian immigrants in the Bay Area. There is more confidence in the tone of the articles and a gradual increase in interest in local and national affairs. There is also an increase in the feeling that home is now in the Bay Area, as evidenced by the analysis of selected terms and an interest in American political affairs, culture, traditions and lifestyle.

But it is only in the years after 2000 that we see the Indian immigrant community involving more and more with affairs in their adopted country. There is also a greater awareness of their position as immigrants, and the acculturation experiences that they have been through. Even after the events of $9 / 11$, though there are some articles about discrimination, the overall involvement in American affairs has risen sharply. The analysis of selected terms reveals that a new identity as an Indian American has now emerged, and for the first time there is mention of putting down roots in the adoptive country.

The editorials over the years, indicate the magazine's position and role, and the editorial staff, by freely seeking the opinion of their readers and evolving with the needs of the community, continue to satisfy their audience though the focus on cultural and community-oriented events continues to be an important part of the magazine.

Limitations of this Study

The magazine has been offering two versions of their publication, the North and South California editions, since 1990 . Though around $75 \%$ of the content is the same, 
there is some difference in the issues. In the interests of time and of doing an in-depth analysis, only the Northern California version was analyzed. It is possible that taking into account the Southern California edition content would have added some additional information about the immigrant experience in the Bay Area. However, since the magazine is based in Northern California, with the maximum readership in this region, the Northern California edition covered the spectrum of immigrant experiences and provided a good understanding for this study.

Also, India Currents is only one of the many magazines that are published in the Bay Area, and its focus is on cultural events. There are other magazines which also focus on politics and community affairs. An examination of the major magazines might have added to this study. However, since culture is an important factor in the acculturation process, and this magazine is distributed free, thus being accessible to all immigrants, the researcher felt that this magazine was the most suitable for the purpose of the study.

\section{Directions for Future Research}

This study has been conducted on one magazine in the Bay Area, CaliforniaIndia Currents, whose focus is on cultural activities and lifestyle-to study the role of immigrant media in the acculturation of Indian immigrants in the Bay Area. However, in recent years, with the growth of the Indian immigrant population in the Bay Area, the number of magazines and newspapers has also compounded. There are many other publications with other areas of focus, both in English as well as in other Indian languages. The immigrant experiences and the narratives which are portrayed in these 
magazines would also add to the understanding of the Indian immigrant experience in the Bay Area.

Another area of study could be Web sites on the Indian immigrant community. Web sites are advantageous in that they can truly create the sense of imagined community for an immigrant, are more immediate and can link to other immigrants in the community. In this age of connectivity through the Internet, websites are also an important part of the magazine's presence on the World Wide Web.

A comparative analysis could also be done between the different kinds of media used and their role in the acculturation needs of the immigrant. Indian television programs are also becoming available in the Bay Area, as are Indian magazines published in India. The study could look into the time the immigrant spends on the different media and the corresponding acculturation needs and levels.

The Indian immigrant is also now becoming more participative in community affairs and politics at the local and the national level. The coverage of this community in the mainstream media is also increasing. It would be interesting to study the differences in the way a topic, such as arranged marriage-which is fairly accepted in the Indian community, but is still an anomaly in American society-is portrayed in the immigrant media and by the mainstream media. 


\section{References}

Amlani, Alzak (2000, February). Honoring the east and the west. India Currents, $46-48$.

Anonymous (1993, September). Proud to be Indian. India Currents, 3.

Azjen, Icek (1989). Attitude, structure and behavior. In A.R. Pratkanis, S. J. Breckler, \& A.G. Greenwald (Eds.), Attitudes, structure and function (pp.241-274). NJ: Lawrence Erlbaum.

Banerjee, Sanjoy (2001a, February). President Bush. India Currents, 20.

Banerjee, Sanjoy (2001b, August). The 2000 census and the Indian-American community. India Currents, $36-38$.

Banerjee, Sanjoy (2003, September). American by Choice. India Currents, Retrieved October 20, 2005, from http://www.indiacurrents.com/news/view_article.html?article id $=44 \mathrm{~d} 0 \mathrm{~d} 1 \mathrm{c} 1505 \mathrm{c} 0$ $\underline{62749600150 \mathrm{aa} 98 \mathrm{~b} 27 \mathrm{f}}$

Banerjee, Shampa (1993, November). Case closed. India Currents, 19.

Barnett, Barbara (2005). Perfect mother or artist of obscenity? Narrative and myth in a qualitative analysis of press coverage of the Andrea Yates murders. The Journal of Communication Inquiry, 29(1), 9-29.

Bay Area Census. Retrieved April 07, 2005, from http://www.bayareacensus.ca. gov/historical/corace.htm

Berdayes, Linda C. \& Berdayes, Vincent (1998). The information highway in contemporary magazine narrative. Journal of Communication, 48(2), 109-124. Retrieved April 07, 2005, from Expanded Academic ASAP Plus database. 
Berry, John W. (1975). Cultural adaptation and psychological differentiation: traditional patterning and acculturative stress. In R.W. Brislin, S. L. Bochner, \& J.Walter (Eds.), Cross-cultural perspectives on learning (pp.34-47). Beverley Hills, CA: Sage.

Berry, John W. (1990). Psychology of acculturation. In R. R. Brislin, (Ed.) Applied crosscultural psychology (pp. 232-253). Newbury Park, CA: SAGE.

Bhatia, Dev A. (1993, January). Cosmetic change. India Currents, M5.

Bhowmick, Ashim K. (1997, January 10). Indian-Americans in N. America. India Times, 27(2), 27. Available from the Ethnic Newswatch database.

Blau, Judith R., Thomas, Min, Newhouse, Beverley, \& Kaave, Andrew (1998). Ethnic buffer institutions: The immigrant press, New York City, 1820-1984. Historical Social Research, 23(3), 20-37.

Carey, James W. (1975). Communication and culture. Communication Research, 2, 173191.

Carey, James W. (1989). Communication as culture, essays on media and society. Boston: Unwin Hyman.

Chandrasekhar, S. (1991, January). From India to America: The story of Indian immigration. India Currents, 13.

Chawda, Aniruddh (2001, May). The ABCD's of a cult sensation. India Currents, 88.

Chawda, Aniruddh (2002a, March). Something about Mira. India Currents, 54 -56.

Chawda, Aniruddh (2002b, March). The dashing director, Ismail Merchant. India Currents, $86-87$. 
Chawda, Aniruddh (2002c, October). Signing in Hollywood. India Currents, 92-94.

Colson, Gigi (1995, May). Where there is noise, there is life. India Currents, C69-70.

Cornitcher, Dawn (May 17, 1999). The explosive growth of ethnic media in the United States. MEDIAWEEK, 9(20), 18. Retrieved April 07, 2005, from Expanded Academic ASAP Plus database.

Cultural Zoo (1987, August). India Currents, 7.

Daniels, Roger (2002). Coming to America-A history of immigration and ethnicity in American life. New York: Harper Collins.

Divakaruni, Chitra (1991) Living in a pregnant time. India Currents, 19.

Entman, Robert. M (1993). Framing: toward clarification of a fractured paradigm. Journal of Communication, 43(4), 51-58.

Eye on Asia and Asian American Legal Defense and Education Fund. (1993, July). The faces of racism. India Currents, 18-19.

Fernandez, Purba (2002). Asian Indian immigration to Canada. In K. A. Berry \& M. L. Henderson (Ed.), Geographical identities of ethnic America- race, space and place. Reno, NV: University of Nevada Press.

Fischetti, P. R. (2000). The ethnic cultures of America. Washington, DC: Educational Extension Systems.

Ganguly, Pia (1993, June). Bachchanalian riots. India Currents, C10.

Gauntlett, David (2000). Web.Studies - rewiring media studies for the digital age. New York: Oxford University Press. 
Gillespie, Marie (2000). Transnational communications and diaspora communities. In S. Cottle (Ed.), Ethnic minorities and the media (pp.164-178). Philadelphia: Open University Press.

Gogula, Ramana K. (1993, November). Reflections. India Currents, 32 - 33.

Gopikrishna, S. \& Kumar, Vandana (1999 December- 2000 January). Indian-Americans of the century. India Currents, $42-46$.

Grover, Pragati (1995a, March). Youth at risk. India Currents, C12.

Grover, Pragati (1995b, November). Milpitas mayor proclaims IBPW day. India Currents, C33.

Gupta, P.R. (1991, January) Word from home. India Currents, 46.

Halperin, Jason (2003, June). Patriot Raid. India Currents, Retrieved October 20, 2005, from http://www.indiacurrents.com/news/view_article.html?article_id=2ble $78 \mathrm{f} 7 \mathrm{fc} 6 \mathrm{e} 28$ $\underline{2 a b 66 f d 75 e 16 d 57 b 99}$

Hsu, Hua (2002, Fall). Ethnic media grows up: will increasing mainstream attention alter the ethnic media landscape? Colorlines, 5(3), 7. Retrieved April 07, 2005, from the Ethnic Newswatch database.

http://www.indiacurrents.com/news/view_article.html?article_id=604cbb802e3dcc3f139f $\underline{\text { 8ea305adacd0 }}$

India Community Center Web site. Indian immigrant population figures. Retrieved April 07, 2005, from $\underline{\mathrm{http}: / / \mathrm{www} \text {.indiacc.org/site/Resources/fact figures }}$

India Currents Web site. About us. Retrieved April 07, 2005, from http://indiacurrents.com/news/ 
Iyengar, Shanto (1996). Framing responsibility for political issues. Annals of the American Academy of Political and Social Sciences, 546, 59-70. Retrieved April 07, 2005, from the JSTOR database.

Jayadev, Raj (2000, April). Breaking the model minority myth. India Currents, 34-36.

Jefferes, Leo (2001). Ethnicity and ethnic media use. Communication Research, 27, 496535. Retrieved April 07, 2005, from Expanded Academic ASAP Plus database.

Jethanandani, Ashok (December 1996-January 1997). s/b ). New content. new look. Changing currents. India Currents, 3.

Kaul, Maharaj (1993, January). Indians rally against communalism. India Currents, M13.

Kim, Young Y. (1978). A communication approach to the acculturation process; a study of Korean immigrants in Chicago. International Journal of Intercultural Relations, 2(2), 197-223.

Kim, Young Y. (1988). Communication and cross-cultural adaptation. Clevedon (England), PA: Multilingual Matters.

Kimani, Ginu (1997, September). A certain innocence. India Currents, 56-59.

Klinger, Edgar W. \& Bierbrauer, Gunter (2001). Acculturation and conflict regulation of Turkish immigrants in Germany: A social influence perspective. In W. Wosinka, R. B. Cialdini, D. W. Barrett, \& J. Reykowski (Eds.), The practice of social influence in multiple cultures (pp.189-205). Mahwah, NJ: Lawrence Erlbaum Associates Publishers.

Korzenny, Felipe \& Schiff, Elizabeth (1992). Texts in contexts. In F. Korzenny, S. TingToomey, \& S. Schiff, (Eds.), Mass media effects across cultures (pp. 11-21). Newbury Park, CA: SAGE. 
Kumar, Arvind (1987a, May). Editorial. India Currents, 2.

Kumar, Arvind (1987b, August). Sheer propaganda. India Currents, 3.

Kumar, Arvind (1987c, December). Call me anything but. India Currents, 3.

Kumar, Arvind (1989a, January). By any other name. India Currents, 3.

Kumar, Arvind (1989b, June). Does Indian mean native? India Currents, 5.

Kumar, Arvind (1989c, July). Proposing a better name. India Currents, 5.

Kumar, Arvind. (1989d, September). The issue of language. India Currents, 5.

Kumar, Arvind. (1991, September). A kinder, gentler police. India Currents, 7.

Kumar, Arvind. (1993, February). Movie madness. India Currents, C11-12, C66.

Kumar, Arvind (1995, April). TIE seminar focus: marketing. India Currents, C50.

Kumar, Arvind (1997, May). Giving back. India Currents, 4.

Kumar, Arvind (1998 December -1999 January). Media literacy. India Currents, 2.

Kumar, Arvind (1999, March). The new Indian-Americans. India Currents, 3

Kumar, Arvind (2000a, February). Get involved. India Currents, 1.

Kumar, Arvind (2000b, June). Immigration act. India Currents, 1. 
Kumar, Arvind (Dec 1996, December - 1997 January). New content, new look. India Currents, 6.

Lassiter, Sybil M. (1998). Cultures of color in America-A guide to family, religion and health. Westport, CT: Greenwood Press.

Lee, Wei-Na, \& Tse, David K. (1994). Changing media consumption in a new home: Acculturation patterns among Hong Kong immigrants to Canada. Journal of Advertising, 23(1), 57-71.

Leonard, Karen (1997). Finding one's own place: Asian landscapes revisioned in rural California. In A. Gupta, \& J. Ferguson (Eds.), Culture power place; explorations in critical anthropology (pp. 121-132). Durham, N.C: Duke University Press.

Malhotra-Singh, Angelina (1999, June). Brownsploitation. India Currents, 38- 40.

Mallapragada, Madhavi (2000). The Indian diaspora in the USA and around the web. In D. Gauntlett (Ed.), Web.Studies - rewiring media studies for the digital age (pp. 179-188). New York: Oxford University Press.

Manas Web site on Indian History. Indus valley civilization. Retrieved April 07, 2005, from http://www.sscnet.ucla.edu/southasia/History/Ancient/Indus.html

Mani, Lakshmi (1998 December - 1999 January). Search for identity - the myth and the reality of the diasporic woman. India Currents, 84.

Mani, Lakshmi (2001, July). Finding an identity. India Currents 86-90.

Mazumdar, Sucheta (1993). South Asians in the United States with a focus on Asian Indians: policy on new communities. In The State of Asian Pacific America, A Public Policy Report (pp. 126-152). Los Angeles, CA, LEAP Asian American Public Policy Institute and UCLA Asian American Studies Center. 
McLeod, Jack M., \& Chaffee, Steven H. (1973). Interpersonal approaches to communication research. American Behavioral Scientist, 16(4), 469-499.

McQuail, Dennis (2000). McQuail's mass communication theory. City, CA: SAGE Publications.

Melvani, Lalvina (1997, February). Indians in cyberspace. India Currents, 31-37.

Mirton, Eliot (1991, August). Love it or leave it. India Currents, 10.

Mody, Bella, \& Valdez, Armando (1984). A study of the third world media in the San Francisco Bay Area. Stanford Center for Chicano Research: Stanford University.

Nagarajan, Ashok (1993, June). Paying India back. India Currents, 6.

Narula, Vivek (1993, April). A journey home. India Currents, C71 - 73.

Nauck, Bernhard (1989). Assimilation process and group integration of migrant families. International Migration, 27(1), 27-48.

Nellore, Ranjani (2003. December 8). Curvature. India Currents. Retrieved April 07, 2005, from http://www.indiacurrents.com/news/view article.html? article_id=3b0681 f8ead2d19c2f0dc435d4c7ef24

New California Media Online Web site. Why ethnic media. Retrieved April 07, 2005, from http://news.ncmonline.com/news/view custom.html?custom page id $=70$

Nishioka, Joyce, \& Dang, Janet (1999, September 8). The future of ethnic media: Hearst, Knight-Ridder eye an appealing market. Asian Week, San Francisco, 21(2), 10. Retrieved April 07, 2005, from the Ethnic Newswatch database.

Novak, Michael (1972). The rise of the unmeltable ethnics. New York: The Macmillan Company. 
NRIlinks.com Web site. Indians in the USA. Retrieved April 07, 2005, from http://nrilinks.com/usa/indians/default.htm

Pandya, Abha (1987). Facing a new reality. India Currents, $10-11$.

Park, Robert E. (1971). The immigrant press and its control. New York: Harper \& Brothers.

Phinney, Jean S. (2003). Ethnic identity and acculturation. In K.M. Chun, P. B. Organista, \& G. Marin (Eds.), Acculturation, advances in theory, measurement, and applied research (pp. 63-82). Washington, DC: American Psychological Association.

Pinsky, Mark (1989, June). The Mexican-Hindu connection-Mexican Indians search for their roots. India Currents, pp. $12-14$.

Pioneer Asian Indian Immigration to the Pacific Coast Web site. First Sikhs, Canada. Retrieved April 07, 2005, from (http://people.lib.ucdavis.edu/tss/punjab/chrono.html\#1897)

Qazi, Javaid (1989, February). College days in Pakistan. India Currents, 10 - 11, 14.

Raman, Priya (2002, May). What's in a name? India Currents, 38.

Ramanan, Nitya (2005, September). Evolutions. India Currents. Retrieved October 20, 2005, from http://www.indiacurrents.com/news/view_article.html?article_id=4da405cd30f05 $\underline{14 \mathrm{fcc} 93 \mathrm{e} 578 \mathrm{c} 594 \mathrm{ec} 12}$

Ramanathan, Sukumar (1997, April). Dollars and sense - the Vivek Ranadive story. India Currents, 38-40, 66. 
Ramanathan, Sukumar (1997, March). That will be a dollar for 10 million bits. India Currents, 40-41.

Redfield Robert, Linton Ralph, \& Herskovits, Melville J. (1936). Memorandum for the study of acculturation. American Anthropologist, 36, 145-148. Retrieved April 07, 2005 , from the JSTOR database.

Riessman, Catherine K. (2003). Narrative analysis. Newbury Park, CA: SAGE.

Rogers, Dinaz K. (1995, June). Why so anti-American? India Currents, 5.

Rohila, Pritam K. (1993, February). Pledge of peace and communal harmony. India Currents, 4.

Roy-Chowdhury, Sandip (1993a, March). Looking for home. India Currents, C11-12.

Roy-Chowdhury, Sandip (1993b, December). Achy breaky Desis. India Currents, 29.

Roy-Chowdhury, Sandip (1999, May). All the world's a stage. India Currents, $45-46$.

Roy-Chowdhury, Sandip (2003a, January). Putting down roots. Retrieved October 20, 2005, from

http://www.indiacurrents.com/news/view article.html?article id=d903b9df9bala 97f66089582fb967fce

Roy-Chowdhury, Sandip (2003b, October). Being brown in America. India Currents, 82 -90 .

Sanzgiri, Jyotsna (1997, June). Resolution for the soul. India Currents, p. 78.

Sanzgiri, Jyotsna (2001, August). Exploring roots. India Currents, p. 94. 
Sarvate, Sarita (1996 December -1997 January). Is true partnership possible? India Currents, 112.

Sarvate, Sarita (2001a, February). Elections serve as rites of passage. India Currents, 160.

Sarvate, Sarita (2001b, April). It is long past the time for the Clintons to say adieu. India Currents, 160.

Scheufele, Dietram A. (2000). Agenda-setting, priming and framing revisited: another look at cognitive effects of political communication. Mass Communication \& Society, 3(2\&3), 297-316.

Seeram, Santosh (1995, April). Finger on the pulse. India Currents, 7.

Shah, Anand (2004, January). The detached desi. India Currents, Retrieved October 20, 2005 , from

http://www.indiacurrents.com/news/view_article.html?article_id=604cbb802e3dc c3f139f8ea305adacd0

Sharma, Archana (2001, August). The door. India Currents, 86 - 88.

Sharma, Radhika (2002, September). Am I home? India Currents, 38.

Sitaraman, Soumya (1999, May). Art: where inner and outer worlds collide. India Currents, $30-32$.

Sitaraman, Soumya (2001, April). The first wave of prodigals. India Currents, 63-66.

Spencer, Liz, Ritchie, Jane, \& O'Connor, William (2003). Analysis, principles and processes. In J. Ritchie, \& J. Lewis (Eds.), Qualitative Research Practice (pp.199218). Thousand Oaks, CA: SAGE. 
Sreenivas, I.S. (1997, June). Destination India. India Currents, 38- 40.

Sreenivas, I.S. (1997, August). Indians behind the Internet. India Currents, 36-38.

Srinivasan, Anusha (2001, July). Dancing lessons. India Currents, 36.

Srinivasan, Rajeev \& Loka, Raghavendra R (2000, June). Indians in the North American political system. India Currents, 6 .

Srinivasan, Rajeev \& Loka, Raghavendra R (1993, December). To stay or not to stay. India Currents, 6.

Stern, Harry (1993, January). Indian Americans horrified. India Currents, M12.

Thakran, Punam (1991, August). Quantum healer. India Currents, 23.

Thiagarajan, Kamala (2004, February). The last laugh. India Currents, Retrieved October 20,2005 , from http://www.indiacurrents.com/news/view article.html?article id=e234f49f3ec06f ab02ba1bf928cff 664

Tillinghast, Diana S. (1998, January-June). Keeping in touch with the Chinese homelands: use of Chinese media in the U.S. Asia Pacific Media Educator, 4, $35-48$.

U.S. Census 2000 (2000). A profile of the Asian population. Retrieved April 07, 2005, from http://www.awib.org/content frames/census $2000 . \mathrm{html}$

Vaid, Jyotsna (1987, July). One from Texas. India Currents, 2.

Vatunk, Ved P. (1991, April). India studies: by whom? for whom? India Currents, 1415. 
Vepa, Prasad (1993, October). Growing up in America. India Currents, 18.

Vishwanath, K., \& Arora, Pamela. (2000). Ethnic media in the United States: an essay on their role in integration, assimilation and social control. Mass Communication \& Society, 3(1), 39-56.

Wagle, N. K (1995, May 5). Images of India: Of "Self" and of "Others". India Abroad (New York edition), 25(31), 2. Retrieved April 07, 2005, from the Ethnic Newswatch database.

Wilson, Clint \& Gueterrez, Felix (1995). Race, multiculturalism, and the media. Thousand Oaks, CA: SAGE.

Winokur, Julie (1995, March). Making your voice heard. India Currents, 7.

Zhou, Min, \& Cai, Guoxuan (2002). Chinese language media in the United States: Immigration and assimilation in American life. Qualitative Sociology, 25(3), 419441.

Zonka, Michelle (1993, June). The flowering of Chhandam. India Currents, C41. 